Hipparion (Equidae, Mammalia) from Venta del Moro (Valencia

\title{
Province, Spain)
}

\section{María Dolores Pesquero, María Teresa Alberdi \& Plinio Montoya}

María Dolores Pesquero [lolap@mncn.csic.es], Departamento de Paleobiología, Museo Nacional de Ciencias Naturales (CSIC), José Gutiérrez Abascal, 2, 28006 Madrid, Spain.

\section{$\underline{\underline{\text { Abstract }}}$}

An abundant record of Vallesian and Turolian Hipparion has given rise to a proliferation of taxonomic names and considerable systematic confusion. This situation is reflected at Venta del Moro (MN13) where specimens have been identified variously as Hipparion similar to the Layna locality and $H$. primigenium the large-sized form, later is indicate the possible presence of $H$. primigenium, $H$. gromovae and another distinct form call Hipparion sp. I, and even these remains are assigned to $H$. cf. $H$. dietrichi. Comparison of Venta del Moro specimens to those from Pavlodar (Kazakhstan, small form), Sahabi (Lybia), Samos (Greece), Höwenegg (Germany) and four Spanish sites: Cerro de la Garita (Concud) (Middle Turolian, MN12), Arquillo, Milagros and Las Casiones (these latter late Turolian, MN13) indicates two species of Hipparion at Venta del Moro: H. primigenium and H. matthewi. These results suggest an extensive dispersion of $H$. matthewi and the persistence of $H$. primigenium in Spain throught the end of the Miocene.

$\underline{\underline{\text { Key words: }}}$ Equidad, Hipparion, Multivariate análisis, Turolian, Late Miocene, Venta del Moro, Valencia, Spain. 


\section{Introduction}

The genus Hipparion is recorded in Eurasia from the early Vallesian to the early Villafranchian (Upper Miocene-Upper Pliocene). Many early Vallesian species and subspecies were named, and most of them were later grouped into the species $H$. primigenium (Forsten 1968; ALBERDI 1974). During the Turolian, the genus widely diversified throughout Eurasia. A size reduction of the medium-sized species ( $H$. mediterraneum, $H$. concudense, etc) led to very small-sized species, which are found not only in the Spanish Turolian (H. gromovae, H. periafricanum), but also in Russia and some Greek sites (H. matthewi, H. macedonicum) (Forsten 1968; ALBERDI 1974; Koufos 1980, 1987; among others). In the following age, Alfambrian (=Ruscinian), the Hipparion record decreases in both number and diversity in all Eurasia, and especially within the Mediterranean area.

The abundant Eurasian record of Vallesian and Turolian Hipparion gave rise to a great proliferation of taxonomic names. In 1968, Forsten began to synthesize them using statistical methods. Later, AlBERDI (1974), by means of statistical methods that combined morphological and biometrical features, set limits to the reduced systematization made by Forsten. Afterwards, ALBERDI (1989) established a total of six morphotypes sensu lato in an attempt to unify the Eurasian and African Hipparion species from the early Vallesian to the early Villafranchian. Recently, several authors have proposed subdividing the species into different genera and subgenera. Based on Chinese Hipparion remains, QIU et al. (1987) proposed grouping several Chinese species into different subgenera. BERNOR et al. (1996, p. 333) placed all species of Hipparion genus into the Hipparionini tribe and grouped them into several genera or group complexes. These include a minimum of four superspcific evolutionary compexes: Hippotherium Complex (include 13 taxa), the Hipparion s.s. group (6 taxa), the Cremohipparion group (7 taxa), and the "Plesiohipparion" group (6 taxa) belonging to the Sivalhippus complex.

The nomenclatorial history of Hipparion species is getting more and more complicated. We believed that this is due to the philosophical differences in relationship to the taxonomical meaning as a tool to do more easily the comparison between genera and species. In our opinion, it is necessary to try looking the features in a morphological 
sense into a more large context to provide a global frame work for defining the morfotype of Hipparion sensu lato (see PESQUERO et al. 2006).

The main goals of this paper are: - to know the more important features of the specimens found in the late Turolian locality of Venta del Moro (Valencia, Spain); - to know the systematic state of the Venta del Moro remains; - to know their relationship with other Eurasiatic species and frame their evolutionary history. This study includes other Eurasiatic and the Sahabi (Africa) forms for comparison in order to get a better description and a more complete multivariate analysis (Fig. 1).

Venta del Moro with an estimated age of 5.8 Ma (OPDYKE et al. 1997) is a locality in the Mediterranean region that has an abundant assemblage of both micro and macrovertebrates belonging to the end of the Miocene (late Turolian, MN 13). Venta del Moro has been extensively discussed (AguiRRE et al. 1973; ROBLES 1974; JiMÉNEZ 1976; Morales \& Aguirre 1976; CAmpo 1976, 1989; Alberdi et al. 1977; Mazo 1977; Morales et al. 1980; RoBles et al. 1983, 1991; Morales 1984; CERDEÑO 1989; LÓPez MARTínez 1989; OpdyKe et al. 1990; PiCKFORD et al. 1993, 1995; VAN GARCíA Flor 1996; MARÍn \& Montoya 1996; Marín et al. 1997; Freudenthal et al. 1998; Martín SuÁrez et al. 1998; DAwson 1999; Made \& Morales 1999; Azanza 2000; MARín 2000), and provides a record fossil plants, mammals and continental mollusks. Thus this locality offers important information on the continental flora and fauna of the Mio-Pliocene transition in the western Mediterranean. It was first excavated during the 1970s by the staff of the Museo Nacional de Ciencias Naturales, Madrid. The excavation of the site was taken up again by the Àrea de Paleontologia of the Universitat de València in 1995.

The fossiliferous beds of Venta del Moro are included in a marls and carbonate sequence, and deposited in a palustrine or lacustrine environment. The fosiliferous beds are stratigraphically located in the upper part of the Los Isidros Member, which belongs to the Venta del Moro-Villatoya Formation (Aguirre et al. 1973; MATHISSEN \& Morales 1981; MARín et al. 2002). Based on small variations in the composition and/or texture of the marls, four beds rich in vertebrate remains have been distinguished in the sequence. These beds have been labeled A to D following the order in which they were excavated. The preservation of delicate vertebrate structures and articulated elements in the base of the marly limestones that constitute bed A is remarkable. In 
contrast, the very biodetritic bed D (sandy marls), which occasionally showed signs of resedimentation (rounded edges), yielded mostly fragmented vertebrate remains. Beds B (grey marls) and C (lignitiferous marls) show intermediate preservation characteristics between both extremes (MARín et al. 2002).

The beds $\mathrm{C}, \mathrm{B}$ and $\mathrm{A}$ constitute a continuous sequence, $1 \mathrm{~m}$ thickness at the most, that represents a single lacustrine cycle. This sequence becomes laterally narrower with a transition to bed D, consisting in lake margin sediments (MARín et al., 2002). All these beds show a quite homogeneus vertebrate assemblages and, therefore, an equivalent age, at the here considered resolution level. Hipparion middle-sized occurs abundantly in all the excavated beds. The scarce remains belonging to the other taxa are distributed as follows: Hipparion large-sized comes from beds A and B, and the smallest remains from bed C.

The Hipparion material from Venta del Moro was described, in part, by ALBERDI (1974) who pointed out that the dental morphology was similar to that of the Hipparion material found in Layna, and that a large-sized lower p3-4 was similar to that found in $H$. primigenium truyolsi. From the remaining material in the locality, Alberdi \& Morales (1981) indicated the possible presence of $H$. primigenium, $H$. gromovae and another distinct form that they call Hipparion sp. I. SONDAAR \& EISENMANN (1995) assigned the Venta del Moro remains to H. cf. H. dietrichi.

\section{Material and Methods}

Material.- The studied material comes from VM, Valencia, Spain (AGUIRRE et al. 1973; MORALES 1984) (Fig. 1).

This material is stored in the Museo Nacional de Ciencias Naturales, Madrid (MNCN), and of the Museu de Geologia de la Universitat de València (MGUV).

Upper teeth: a right and left series P2-M3 of the same individual, one right series P3M3 and one left series P2-M3. Isolated teeth: 33 P2, 77 P3-4, 71M1-2 and 31 M3. Milk teeth: 10 D2 and 34 D3-4.

Lower teeth: a complete jaw with incisors and a right and left series p2-m3; one right mandible with p2-m3, one series p2-m3, one series p2-p4 and one series p4-m2; isolated teeth: 30 p2, 40 p3-4, 63 m1-2 and 22 m3. Milk teeth: three d2 and d3-d4; and eight petrosal bones. 
Appendicular skeleton: five humeral distal fragments; one complete radius and 10 distal fragments; three McII fragments, 41 McIII (10 complete), two McIV fragments; nine tibiae distal fragments; 14 calcanea (three complete); 37 astragali (27 complete); three MtII fragments, 18 MtIII (seven complete), eight MtIV fragments; 24 1PhIII complete and eight fragments, 26 2PhIII complete and four fragments, one 3PhIII complete; 11 scaphoids, 11 magnums, six lunata, six trapezoids; 19 ectocuneiforms, 12 naviculars, 10 cuboids; eight complete first lateral phalanges and one fragment, and one complete second lateral phalanges.

Material for comparison included Turolian forms from Spanish localities Hipparion concudense PIRLOT 1956 from CG (Concud); Hipparion gromovae VILLALTA \& CRUSAFONT 1957 from ML; Hipparion gromovae and Hipparion periafricanum VILLALTA \& CRUSAFONT 1957 from ARQ and Hipparion gromovae and Hipparion periafricanum from KS (PESQUERO 2003). Also included remains from Central Europe and Asia, of the Vallesian and Turolian forms from Höwenegg (Germany; BERNOR et al. 1997; and raw data that he send us from Höwenegg), Samos (Greece, BERNOR \& TOBIEN 1989), and Hipparion elegans (small form from PAV Kazakhstan, GromovA 1952, and own data), and from Africa we include remains from Sahabi (BERNOR \& SсоTT 2003).

Methodology.- The nomenclature and measurements follow the recommendations of the 'Hipparion Conference', New York, November 1981 (EISENMANN et al. 1988). All dimensions are expressed in millimetres.

We used morphological and morphometric characters (Fig. 2), and degree of wear on upper and lower cheek teeth (i.e. germ to unworn teeth, I, II, III, IV, and V) proposed by AlBerdi (1974: figs. 1 and 2). Whenever possible, we include references to mandible characters on the scarce specimens available. We calculated the hypsodonty index on teeth that were unworn or only slightly worn. This index is defined as the ratio between the mesio-distal length (2) and the height of the unworn teeth (1) (EISENMANN et al. 1988: figs. 6-8). Dimensions of the teeth are presented in bivariate plot using the customary P3-4, M1-2, p3-4, and m1-2. Two bivariate plots were generated in order to analyze the robustness and/or slenderness of the metapodials. One plot, following BERNOR et al. (1990), juxtaposed the maximum length (McIII1 or MtIII1) versus the distal articular breadth (McIII11 or MtIII11). The second compared maximum length 
versus minimal breadth of the diaphysis (McIII3 or MtIII3). Also bivariate plot were generate on 1PhIII. Over the bivariate plots with calculated 95\% confidence ellipses to better describe the range of variability in the analysed samples. Bivariate analyses: we perform an ANOVA and use Tukey's Honestly Significant Difference to determine differences between pairs. Bivariate and multivariate analyses were performed with the numerical data to establish size similarities. Metapodials, astragali, and first phalanges were analysed using principal component analysis (PCA) to evaluate similarities and/or differences among size and length the different Hipparion remains of VM and to assess their relationship with the remains from other localities. After these groups were identified, based on the PCA, we preformed a discriminant analysis (DA) following the Mahalanobis method with the aim of maximized the separation between the groups being identified and also to evaluate whether the centroids differ significantly or nor, and often to identify specimens not included in the original analysis which established the groups. Calculations were made using SPSS 11.0.

Abbreviations.- DPOF: dorsal preorbital fosse; P/M: upper teeth; p/m lower teeth; L: length; W: breadth; HI: Hypsodonty index; Apre: Anterior-prefossette; Dpre: Distalprefossette; Apof: Anterior-postfossette; Dpof: Distal-postfossette; McIII and MtIII: metacarpal and metatarsal respectively; SI: Slenderness index; $1 \mathrm{PhIII}, 2 \mathrm{PhIII}$ and 3PhIII: first, second and third phalanges of the third digit respectively; PCA: Principal Components Analysis; DA: Discriminant Analysis. Localities: ML: Milagros; KS: Las Casiones; ARQ: El Arquillo; VM: Venta del Moro; CG: Cerro de la Garita (Concud), HO: Höwenegg; SA: Samos; PAV: Pavlodar (small size); and SH: Sahabi.

\section{$\underline{\underline{3, \text { Results }}}$}

\section{Morphological and univariate analysis}

The bivariate plot of the dental measurements indicates that the remains from VM are clearly gathered within the distribution of the PAV, KS, ARQ, ML and SA remains, overlapping each other to a great extent (Fig. 5). The scarce teeth from Samos are place among small remains of $H$. matthewi or between $H$.matthewi and $H$. periafricanum. The bivariate analyses performed of the upper teeth clusters the majority of the VM teeth with those from KS; PAV remains are distributed among the largest from VM and those from ML and ARQ within the VM smallest ones. H. periafricanum teeth are clearly 
smaller. Nevertheless, in the P3-4 bivariate plot, three premolars from VM are distributed among those of HO (MNCN-11307, VV-1591, VV-4699). The greater part of the VM teeth are distributed among those of PAV, KS, ARQ, ML, and Samos (Fig. 5).

As for the lower teeth, the largest one is a m1-2 (MNCN-10982), very large in size, that is placed into the $\mathrm{HO}$ distribution. Its morphology is similar to $H$. primigenium remains, whose occlusal surface presents a very complicated enamel wrinkle. The KS teeth distribution includes the larger part of the VM remains as well as the ones from PAV, ML, ARQ, and SA. The PAV remains are distributed among those of medium size from VM and those from ML and ARQ among the smallest.

The metapodials bivariate analyses (Fig. 6) indicate that the McIII examples as well as the MtIII ones from VM are very similar to those from PAV, ML, SA, and SH. The $H$. periafricanum remains rest out the $H$. matthewi distribution. The analyzed metapodial samples of these deposits have a similar length to those from CG, but their diaphysis breadth is larger and more robust. McIII's from Milagros are shorter but similar in breadth to those from PAV, SA and VM. That is, they are smaller but more robust.

With regard to the first phalanges, two analyses have been carried out: one with the anterior $1 \mathrm{PhIII}$ and the other one with the posterior 1PhIII (Fig. 7). In both cases, the distribution of the VM phalanges coincides to a large extent with that from PAV (specially the posterior 1PhIII) and overlap with that from KS. In spite of having similar length, the 1PhIII coming from CG detaches itself from the VM sample due to the small size of its diaphysis, in VM, that gives it a more graceful appearance. The ML remains are place betweem $H$. periafricanum and $H$. matthewi distributions. There is a 1PhIII posterior (VV-11216) that on place in the latter group.

The ANOVAs analyses with regard to the McIII, the MtIII, the astragalus and the first phalanges indicate the significant differences between VM samples and the others localities analysed in this paper (Table 5). As for the McIII, the measures 3 and 7 are 0.05 significantly differents the $\mathrm{CG}, \mathrm{HO}$ and $H$. periafricanum remains, while the measure 1 of VM are similar in all localities analysed, except from KS and ML that are only one specimen. With regard to the metatarsals, their lengths are comparatively similar with all localities analyses, while measures 3 and 7, breadth dimensions, are significantly differents that $\mathrm{CG}, \mathrm{HO}$ and $H$. periafricanum, that indicate significant 
differences in robustness. In the astragali remains some parameters (measures 1, 2 and 4) indicate that VM remains are significantly differents (0.05) from CG, $\mathrm{HO}$ and $H$. periafricanum remains, and very similarities to KS, PAV, and SA. Only two VM astragali are significantly smaller in measures 2 and 4 than the bulk of the remains from this site and are very similar to those from ML except for the navicular articulation. ML have astragali significantly different than VM. The anterior 1PhIII from VM are significantly different only that $H$. periafricanum in measures 1 and 5 and also that CG and $\mathrm{HO}$ in measure 3, and very similat to KS, ML, PAV and SA, while the posterior phalanges are significantly different those CG, $\mathrm{HO}$ and $H$. periafricanum from Las Casiones in measure 1, and measures 3 and 5 are similar that occurred in the anterior phalanges. To sum up, no significant differences between those from VM remains and those of $H$. gromovae from KS and ML, H. elegans from PAV, and H. matthewi from SA are found. Consequently, we suggest that this high similarities among them recommend synonymized among them, and the priority correspond to $H$. matthewi.

\section{Multivariate analysis}

Principal component analysis (PCA).- The Principal component analysis allows us to evaluate the similarities and/or differences in size and length between the studied VM remains and the samples of the other localities included for comparison.

The PCA of skeletal measurements, enables us to identify two main groups with regard to the size and length. The first group clusters the specimens belonging to CG and HO as they are larger in size while the second one joins the relatively smaller specimens from VM, KS, PAV, SA, SH, and ML.

Regarding second group, the VM remains, those of $H$. matthewi from PAV, KS, SA and SH overlap among them, while the ML remains are isolated since they are the smallest in size. As for the McIII PCA (Fig. 8; Table 6), the first component is mainly influenced by the proximal articular breadth (McIII5) and distal maximal depth of the medial condyle and distal maximal articular breadth (McIII14 and McIII11). In the second component, the most influential variables are the maximum lengths (McIII2 and McIII1) and the antero-posterior measurements of depth of the diaphysis (McIII4). The variance accumulated by the two component reached $87.43 \%$. In this way, we observe that among smaller size metacarpals, some from PAV and the one from KS are more 
robust. The ML specimen is the smallest in size and those from CG and HO are the largest and the most robust.

The results of the MtIII PCA are similar to those of the McIII PCA (Fig. 9). In the first component, the most influential characters are the maximal diameter of the articular facet for the third tarsal, distal minimal depth of the lateral condyle and distal maximal supra-articular breadth (MtIII7, MtIII13 and MtIII10). In this component we observe: (1) one group showing a more robust MtIII, (2) other group that exhibits a more slender MtIII, and (3) another group with the smallest remains of $H$. periafricanum from Casiones. The most robust MtIII correspond to HO and CG Hipparion, while the most slender MtIII belong to VM, PAV, KS, SA y ML (Tabla 6). In the second component the most important variables are the maximal lengths (MtIII2 and MtIII1) and the proximal articular breadth (MtIII5). These two components accumulated a variance of 89.03\%. In the second group the shortest metapodial is that from ML, and the longest is from Samos, and in general, the metatarsals from VM, PAV, and KS overlap.

The astragalus PCA differentiates three groups: the first includes CG and HO remains as well as one from Venta de Moro (VV-696), the second comprises all the remains from VM (with the exception of VV-696), PAV, KS and ML (Fig. 10), and the third include only $H$. periafricanum from KS. In this analysis, all the characteristics influence the first component; therefore, this component emphasizes the size of the different specimens. The breadth of the trochlea (AS3) carries the most weight in the second component. The first component clearly separates all the groups. In the second group, the smallest remains in size correspond to those from ML and two specimens from VM (VV-1893, VV-3304) that overlap among them. Both components accumulated a variance of $97.13 \%$ (Table 6).

In the calcaneus PCA only three specimens are from VM, two of them are included into the PAV and KS distribution - greatly overlapping between them-, while the other one (VV-1894), smaller in size, is similar to the smallest astragali from ML.

As for the first phalanx PCA (Fig. 11, Table 6), the most influencial for the first component are the proximal breadth, the minimal breath, and the distal breadth at the tuberosities (1PhIII4, 1PhIII3, and 1PhIII6). With regard to the second component, the anterior length and the maximal length are the most important variables (1PhIII2 and 1PhIII1). Both components accumulated a variance of $87.35 \%$. In this diagram, the VM 
specimens overlaps those from PAV and KS, and, at the sametime, those from PAV are separated into two individualized groups, corresponding to the anterior and posterior phalanges (Fig. 11, Table 6). The CG and HO phalanges have similar lengths to VM but their breadths are larger (more robust) and those from ML are the smallest.

Discriminant analysis (DA).- Discriminant analysis was carried out on the results obtained from the PCA, to the aim to maximized the separation between the groups being identified. As consequence of PCA results, the bulk of the VM remains are now joined to the KS, PAV, SA and SH ones; as for, the small remains from VM, they lie with those from ML, while $H$. concudense from CG and $H$. primigenium from $\mathrm{HO}$ remains as independent groups. The McIII DA separates the VM $+\mathrm{KS}+\mathrm{PAV}+\mathrm{SH}$ group from the other localities (Fig. 12, Table 7). All of the analyzed groups have been correctly identified in $100 \%$ of the cases.

The MtIII DA also gives these results, but there are certain overlappings with some specimens from CG (Concud) in 5.3\% of the cases (Fig. 13, Table 7).

The astragalus DA confirms the separation observed in the PCA. The specimens from $\mathrm{VM}+\mathrm{KS}+\mathrm{PAV}+\mathrm{SA}$ are correctly classified in $87 \%$ of the cases, overlap with CG in $11.7 \%$ (9 specimen) and in $1.3 \%$ (1 specimen) with $H$. primigenium from $\mathrm{HO}$; the remains from CG are correctly identified in $94.4 \%$ of the cases and overlap with those from VM + KS + PAV + SA in 5.6\%; those from ML + VM (smallest) are correctly identified in $100 \%$ of the cases (Fig. 14, Table 7).

In the 1PhIII DA (Fig. 15, Table 7), VM + KS + PAV + SH are correctly clasified in $87.5 \%$, overlap with CG in $4.2 \%$ of the cases, with $\mathrm{HO}$ in $8.3 \%$ (4 specimen); the remains from ML and VM (smallest) are correctly classified in $100 \%$ of the cases.

\section{Discussion}

The obtained results from the frequency analyses for as well as from the PCA, indicate the presence of a predominant form of Hipparion in VM, and a much less important group of remains significantly larger or smaller in size. There are four teeth that are larger in size located in the HO distribution (VV-4699, VV-1591, MNCN-11307, MNCN-10982). This last one is comparable in size and morphology with $H$. primigenium. Regarding the postcraneal skeleton (Fig. 4), only one bone, an astragalus (VV-696) exceeds the size of the other remains. On the other hand, six bones -two 
astragali (VV-1893, VV-3304), one calceneum (VV-1894), two 2PhIII (VV-833, VV6182), and one 1PhIII (VV-11216)-, are located below the distribution of VM, PAV, KS, SA and SH and near the distribution of ML. Latter remains are still significantly larger than those of $H$. periafricanum (Table 5).

To sum up, the largest remains from VM site are equivalent to $H$. primigenium remains from several European localities. The m1-2 and P3-4 morphology (MNCN-10982, VV4699, VV-1591, MNCN-11307) are very similar to those of $H$. primigenium teeth, with a very complicated enamel folding on its occlusal surface and similar degree of hypsodonty. The biggest astragalus is also included among the distribution of $H$. primigenium. In the comparison between VM and KS remains (PESQUERO 2003) indicates that in latter locality only a few remains were attributable to $H$. primigenium (a distal tibia fragment KS-1243, and a second lateral phalange KS-2309). And that they were similar in size to the VM largest remains.

Both the morphology and dimensions of the majority of VM remains are very similar to the ones of KS which were assigned to Hipparion gromovae by PESQUERO (2003). This form, in the two deposits, is charaterized by both a dentition and a postcraneal skeleton showing a medium-small size, smaller than that of Hipparion concudense from CG and bigger than that of Hipparion from ML. The dentition, in KS, PAV, SA as well as in VM, is characterized by a medium folding enamel in the occlusal surface and a medium hypsodonty. The metapodials figured (Figs. 4a to 4d) correspond to scale of specimens from VM, H. matthewi.

The VM smallest remains are similar to those from the ML deposit, and were assigned to Hipparion gromovae by AlBERDi \& AlCALÁ (1989-90). Due to the scarcity of remains, an exhaustive morphological description can not be carried out. ANOVAs analyses have made possible to separate the smallest VM remains both from the rest of the remains belonging to this location and from the KS smallest remains that were attributed to Hipparion periafricanum by PESQUERO (2003).

How we sugget above the comparative analysis among $\mathrm{VM}+\mathrm{PAV}+\mathrm{KS}+\mathrm{SA}+\mathrm{SH}$ we obtain a first result relate to the taxonomical place of the predominant form of Hipparion in VM. That is the clear resemblance among them and consequently we synonymized $H$. gromovae and $H$. elegans with $H$. matthewi that was the priority rules. 


\section{Systematic Palaeontology}

Order Perissodactyla OwEN, 1848

Infraorder Hippomorpha WooD, 1937

Superfamily Equoidea HAY, 1902

Family Equidae HAY, 1902

Genus Hipparion CHRISTOL, 1832

Hipparion primigenium (V. MEYER 1829)

or Hippotherium primigenium (sensu BERNOR et al. 1996)

Holotype: lacking

Lectotype: Fragment of right lower cheek teeth (P2-P4), SENK M1421 from Eppelsheim (Rheinhessen, Germany), stored in the Senckenberg Museum (Frankfurt, Germany) sensu WoOdBURne et al. (1996). Referred in v. MeYer (1833: tab. XXXXXXI, figs. 17, 18 and 19).

Type locality: Eppelsheim, Alemania (MN9).

Stratigraphic distribution: Late Miocene, Vallesian and Turolian, from around 11.1 to 6.5 Мa.

Geographic distribution: Eurasia: Spain, Portugal, Greece, Turkey, Russia, China, Pakistan, India, among others; Africa: North and East Africa.

Material: m1-2 (MNCN-10982), three teeth P3-4 (MNCN-11307, VV-1591, VV-4699), and an astragalus (VV-696) (Figs. 3 and 4).

Emended diagnosis: robust Hipparion species; large upper and lower cheek teeth, with characteristic enamel plications that decrease with wear. Robust metapodials that become more slender in later populations of this species but with the same structure. Well developed DPOF.

Description: From VM, the only material assigned to Hipparion primigenium was a m1-2, three P3-4 and an astragalus, which are included in this species due to its size. The molars are only slightly hypsodont and the morphology of the enamel on the 
occlusal surface is complicated, similar to that of populations of this species from the Calatayud-Teruel Basin.

Hipparion matthewi (ABEL 1926)

(or Cremohipparion matthewi, sensu BERNOR et al. 1996)

Synonyms:

1957 Hipparion gromovae VILLALTA \& CRUSAFONT 1957.

1968 Hipparion elegans Gromova 1952, in FORSTEN 1968, p.53.

Holotype: Skull OK-557 Geological Insttiute, Budapest. Following FORSTEN (1968) this was referred (photograph) in KoRMOs (1911 according to GromOVA 1952). Described by ABEL (1926).

Type locality: Unknown locality of Samos (Greece).

Stratigraphic distribution: Late Turolian of Samos.

Geographic distribution: This species has been found at several localities in the Esatern Mediterranean; besides Samos it is also known from Salonike and Maragha. It is also found in Pavlodar (Kazahkstan, Asia). In Spain it is found in the Teruel, Cabriel and Granada Basins.

Material: specified in the "Materials and Methods" sections, except for three upper P34 (MNCN-11307, VV-1591, VV-4699), one m1-2 (MNCN-10982) and an astragalus (VV-696) belonging to $H$. primigenium, two astragali (VV-1893, VV-3304), one calcaneum (VV-1894), one 1PhIII (VV-11216), and two 2PhIII (VV-6182, VV-833) belonging to $H$. matthewi ssp. (Figs. 3 and 4).

Diagnosis: Slender, medium-small sized Hipparion. Molars are hypsodont and the design of enamel of the occlusal surface is moderate on both the upper and lower teeth. Small oval protocone that only merges with loph in cases of advanced wear, and pli caballins single in the mayority. The protostylid is weakly developed on the lower molars and missing at times on premolars. Absent ectostylid; small oval protocone that only merges with loph in cases of advanced wear. Bones of the postcranial skeleton are slender and the metapods elongate and slender.

Description: The upper teeth are characterised by their medium to small size and the moderate enamel plication. The protocone is lenticular in shape on teeth showing little wear and flattened and rounded on molars that are worn. Mean length of the premolars 
is $6.4 \mathrm{~mm}$ and $6.9 \mathrm{~mm}$ in molars (Table 1). The protoloph in $11 \mathrm{P3}-4$ is only joined in cases of advanced wear $(<1 \mathrm{~cm})$. The fossette folds are medium (premolars: Apref.: 0-9 mode 6; Dpref.: 1-8 mode 6; Aposf.: 0-7 mode 4; Dposf.: 0-2 mode 1. Molars: Apref.: 0-7 mode 1; Dpref.: 1-8 mode 5; Aposf.: 1-7 mode 2; Dposf.: 0-5 mode 1) following AlberDi (1974). The caballine fold varies between 0 and 2, while the mode for both molars and premolars is 1 . The hypsodonty index is 2.5 in P3-4 and 2.4 in M1-2 (Table 2).

In the lower teeth the premolars are more robust than the molars. The enamel is smooth with a rounded oval double-knot that becomes more angular with wear. The linguaflexid is wide and shallow in unworn teeth and deeper in worn teeth. The ectoflexid is slightly developed in premolars and very developed in molars, where it crosses isthmus, between preflexid and postflexid, reaching the linguaflexid only in some cases. The protostylid is not very developed and is only joined to the protoconid in three m1-2 (MNCN-11061, MNCN-11105a, MNCN-11105b) in states of advanced wear $(<1 \mathrm{~cm})$. The hypsodonty index is 2.5 in p3-4 and 2.7 in m1-2 (Table 2).

The postcranial remains are medium to small in size (Table 3). In the metacarpians the angle between the magnum facet and the hamatum facet is open, with a mean of $120^{\circ}$ in eight measured specimens. The hamatum facet is elongated. In three samples it is divided into two facets with a canal between them and moreover, it has two McIV facets. The magnum facet is subtriangular in shape with a well developed and rounded muscular insertion area. The gracility index (measures 1/3) in the metacarpians is 10.3 (Table 4).

In the metatarsal, the cuboid facet varies in size among samples. In samples where the facet is most developed it is subquadrangular in shape and in samples where it is less developed it is subrounded. In five measured samples, the angle formed between the cuboid facet and the large cuneiform was, on average $137^{\circ}$. The small cuneiform facet is observed only in samples where it is well-developed and is subquadrangular in shape. Some samples have two MtIV facets, both rounded, being more clearly obserbable the one in the posterior side. The facet belonging to the muscular insertion of the grand cuneiform has a variable development. The metatarsals slenderness index (measures $1 / 3$ ) is 9.5 (Table 4). 
They are morphological differences between the forelimbs first phalanges and the hind extremities ones. In this way, the proximal articulation facet is oval-elongated in the former and sub-cuadrangular in the latter; the ventral groove is more pronounced in the posterior phalanx, and in general the anterior phalanges are more slender than the posterior ones (Table 4).

The astragalus shows an elongated articular surface for the calcaneus (c) that sometimes contacts with the biggest condyle of the trochlea. The facet $b$ has a small facet aside, isolated and elongated, that in only one specimen is connected to the facet $\mathrm{b}$ forming a continuous articular surface. The articulation facet with the navicular takes a subtriangular form and the muscular insertion area has a variable development. The cuboides facet is subtriangular and it forms a prominent angle with the navicular facet (Table 4).

Hipparion matthewi ssp.

Material: two astragali (VV-1893, VV-3304), one calcaneum (VV-1894), one 1PHIII (VV-11216), and two 2PhIII (VV-6182, VV-833) (Fig. 4). The astragalus VV-1893 and the calcaneus VV-1894 belong to the same individual. These six bones are small in size, and they are the smallest remains of VM of $H$. matthewi, but still significantly larger than those of Hipparion periafricanun from KS and similar to the Milagros remains (Table 5). Hipparion from latter locality is smaller than Venta de Moro, Casiones and Arquillo into the same species of $H$. matthewi.

\section{Conclusions}

In the Venta del Moro assemblage (late Turolian, MN13) there are three different Hipparion forms represented. The first one is assigned to Hipparion primigenium (or Hippotherium primigenium sensu BERNOR et al. 1996) by means of the size and morphology of the four existing molar and an astragalus. The second one, which is predominant form in VM, corresponds to a medium-small size Hipparion that we assigned to Hipparion matthewi (or Cremohipparion matthewi, sensu BERNOR et al. 1996 ). The third one includes the smallest remains in size and it is attributed to a subspecies of Hipparion matthewi. Due to the scarcity of remains we prefer not to give a subspecific name to these specimens: Hipparion matthewi ssp. 
The material assigned to Hipparion primigenium is very scarce. In spite of this, it is possible to observe claracteristics both in size and morphology that are identical to the ones of $H$. primigenium from Europe and especially with Höwenegg (Germany).

The bulk of the remains has been assigned to the species Hipparion matthewi because of its similarities in size as well as in morphology with $H$. gromovae from different Spanish localities, H. elegans from Pavlodar and H. matthewi from Samos and Sahabi. The detailed study of the Venta del Moro material allows us to observed some differences into the bulk remains. To evaluate these differences at specific level is difficult but they can indicate different environmental conditions and could be considered at subspecific level. Therefore, we named the Venta del Moro smallest remains in size (very similar to the Milagros form) as $H$. matthewi ssp. In the future, a detailed revision of Hipparion material from Milagros could solve this question.

These results could be indicate an extensive dispersion of $H$. matthewi from Asia to Europe occidental. Also the presence of $H$. primigenium in Spain until the end of Miocene indicate a survival of this species through out time.

\section{Acknowledgements}

We thank to R BERNOR and R. SCOTT for their critical reviews of this manuscript and valuables comments. The field works in Venta del Moro have been supported, since 1995, by financial aid from the Conselleria de Cultura of the Generalitat Valenciana. The authors also wish to express their thanks to Curators of the Museu de Geologia de la Universitat de València and Museo Nacional de Ciencias Naturales, CSIC, Madrid. J. WATKINS and S. DOMINGO revised the English text. This work has been made possible thanks to Research Projects DGICYT: PB98-1250, PB98-0513, PB98-0691-C03-01, BTE2001-1684, BTE2002-00410 and BTE2003-0301.

\section{$\underline{\underline{\text { References }}}$}


ABEL, O. (1926): Die Geschichte der Equipen auf dem Boden Nordamerikas.- Verh. Zool. Bot. Ges., Wien, 푸: 159-164.

Aguirre, E., Robles, F., Thaler, L., López Martínez, N., Alberdi, M.T., \& Fuentes, C. (1973): Venta del Moro, nueva fauna finimiocena de Moluscos y Vertebrados. - Estudios Geol.., $\underline{\underline{\mathbf{2 9}}}$ : 569-578.

Alberdi, M. T. (1974): El género Hipparion en España. Nuevas formas de Castilla y Andalucía, revisión e historia evolutiva. - Trabajos N-Q, 1: 1-146.

Alberdi, M. T. (1989): A review of Old World Hipparionine Horses. - In: D.R. Prothero \& R.M. Schoch (Eds.): The evolution of Perissodactyla. - p. 234-261; Oxford University Press, New York and Oxford.

Alberdi, M.T. \& AlcalÁ, L. (1989-1990): El género Hipparion en la fosa de Alfambra-Teruel. - Paleontologia i Evolució, 23: 105-9.

Alberdi, M.T., LóPez, N., Mazo, A.V. \& Morales, J. (1977): Venta del Moro y las faunas de vertebrados finimiocenas de España. - Estudios Geol.., $\underline{\underline{33}}$ : 589-591.

Alberdi, M. T. \& Morales, J. (1981) : Significado biostratigráfico del género Hipparion en España. - Teruel, 뜨: 61-66.

AzAnzA, B. (2000): Los Cervidae (Artiodactyla, Mammalia) del Mioceno de las cuencas del Duero, Tajo, Calatayud-Teruel y Levante. - Mem. Mus. Paleont. Univ. Zaragoza, 요 1-376.

Bernor, R. L., Koufos, G. D., Woodburne, M. O. \& Fortelius, M. (1996): The Evolutionary History and Biochronology of European and Southwest Asian Late Miocene and Pliocene Hipparionine Horses. - In: R.L. Bernor, V. FALBUSCH, \& H.W. MitTMAnN (Eds.): The Evolution of Western Eurasian Neogene Mammal Faunas. - p. 137-154; Columbia University Press, New York.

Bernor, R. L., Kovar-Eder, J., Lipscomb, D., Rögl, F., Sen, S. \& Tobien, H. (1988): Systematic, stratigraphic, and paleoenviromental, contexts of first-appearing Hipparion in the Vienna Basin, Austria. - J. Vert. Paleont., 昼: 427-452.

BERNOR, R.L. \& SCOTT, R.S. (2003): New interpretations of the systematics, biogeography and paleoecology of the Sahabi hipparions (latest Miocene) (Libya).Geodiversitas, 로: 297-319. 
Bernor, R.L. \& Tobien, H. (1989): Two Small Species of Cremohipparion (Equidae, Mammalia) from Samos, Greece.- Mitteilungen der Bayerischen Staatssammlung für Paläontologie und Historische Geologie, $\underline{\underline{\mathbf{2 9}}}$ : 207-226.

Bernor, R.L., Tobien, H., HayeK, L.C. \& Mittmann, H.W. (1997): Hippotherium primigenium (Equidae, Mammalia) from the late Miocene of Höwenegg (Hegau, Germany). - Andrias, 토: 1-230.

Bernor, R. L., Tobien, H. \& Woodburne, M. O. (1990): Patterns of Old World Hipparionine evolutionary diversification and biogeographic extension. - In: E.H. Lindsay, V. Fahlbusch, \& P. Mein (Eds.): European Neogene Mammal Chronology. - p. 263-319; Plenum Press, New York.

CERDEÑo, E. (1989): Revisión de la Sistemática de los rinocerontes del Neógeno de España. - Editorial de la Universidad Complutense de Madrid, 429 p., 64 tab., 51 làm. Christol, J. DE (1832): Description. - Ann. Sc. Indust. Midi, France, 1: 1-180.

Dawson, M.R. (1999): Bering Down: Miocene dispersals of land mammals between North America and Europe. - In: G.E. Rössner \& K. HeIssig (Eds.): The Miocene Land Mammals of Europe. - p. 473-483; Verlag Dr. Friedrich Pfeil, Munchen.

Eisenmann, V., Alberdi, M. T., De Giuli, C. \& Staesche, U. (1988): Collected papers after the "New York International Hipparion Conference, 1981". - In: M. WoOdBurne \& P. SondaAR (Eds.): Studying fossil Horses, 1, Methodology. - p. 1-77; E.J. Brill, Leiden.

Forsten, A. (1968): Revision of the Palearctic Hipparion. - Acta Zool. Fennica, $\underline{\underline{119}}$ : 1-131.

Freudenthal, M., Mein, P. \& Martín SuÁrez, E. (1998): Revision of Late Miocene and Pliocene Cricetinae (Rodentia, Mammalia) from Spain and France. - Treb. Mus. Geol. Barcelona, ㄹ: 11-93.

GARCíA FlOR, J. (1996): Malacología del Neógeno continental de la cuenca del río Cabriel (Albacete, Valencia). Tesis Doctoral, Universitat de València, 274 pp.

Gromova, V. (1952): Le genre Hipparion. Trudy Paleontological Institut, URSS $\underline{\underline{36}}$ : 1478 (Trad. J. de SAINT-AUBIN).

HAY, O.P. (1902): Bibliography and catalogue of the fossil Vertebrata of North America.- Bull. U. S. Geol. Surv., 28: 1-868. 
JiMÉNEZ, E. (1976): Quelonios fósiles de Venta del Moro (Valencia). - Trabajos N-Q, ㅍ: $117-128$.

KoRMOS, T. (1911): Der Pliozäne Knochenfund bei Polgardi. - Földtani Közlöny, $\underline{\underline{41}}$ 48-84.

Koufos, G.D. (1980): Paleontological and stratigraphical study of the continental neogene deposits of the Axios basin. - Sc. Ann. Fac. Phys. Math., University of Thessaloniki, 19: 1-322.

Koufos, G.D. (1987): Study of the Turolian Hipparions of the Lower Axios Valley (Macedonia, Greece). 1. Locality “Ravin de Zouaves-5” (RZO). - Geobios, 20. 293312.

LÓPEZ MARTínez, N. (1989): Revisión sistemática y biostratigráfica de los Lagomorpha (Mammalia) del Terciario y Cuaternario de España. Memorias del Museo Paleontológico de la Universidad de Zaragoza: $\underline{\underline{3}}, 350$ pp.

MAde, J. VAn Der \& Morales, J. (1999): Family Camelidae. - In: G.E. RÖssner \& K. HEISsig (Eds.): The Miocene Land Mammals of Europe. - p. 221-224; Verlag Dr. Friedrich Pfeil, Munchen.

MARín, M.D. (2000): Estudio tafonómico del yacimiento mioceno de vertebrados de Venta del Moro (Valencia). Tesis de Licenciatura, Universitat de València, 183 pp.

MARín, M.D. \& MonTOYA, P. (1996): Composición de la asociación de vertebrados del Mioceno superior de Venta del Moro (cuenca del Cabriel, Valencia). - In: T. PALAcios \& R. GozAlo (Eds.): Comunicaciones de las XII Jornadas de Paleontología. - p. 78-80; Universidad de Extremadura, Badajoz.

Marín, M.D., PeÑAlver, E. \& Montoya, P. (1997): Recuperación y restauración de los materiales paleontológicos de Venta del Moro (Valencia). - In: A. GRANDAL, J.C. Gutiérrez Marco, \& L. SAntos (Eds.): Comunicaciones de las XIII Jornadas de Paleontología. - p. 199-202; A Coruña.

Marín, M.D., Santisteban, C. De, Merino, L. \& Montoya, P. (2002): Petrographic study of macrovertebrate fossil bones from the Upper Miocene of Venta del Moro (Valencia, Spain). - In: M. De ReNZI et al. (Eds.): Current topics on Taphonomy and Fossilization. - p. 345-352; Ajuntament de València.

Martín SuÁrez, E., OMs, O., Freudenthal, M., Agustí, J. \& ParÉs, J.M. (1998):

Continental Mio-Pliocene transition in the Granada Basin. - Lethaia, $\underline{\underline{31}}$ : 161-166. 
Mathisen, M. \& Morales, J. (1981): Stratigraphy, facies and depositional environments of the Venta del Moro vertebrate locality, Valencia, Spain. - Estudios Geol.., 37: 199-207.

Mazo, A.V. (1977): Revisión de los mastodontes de España. Tesis Doctoral, Universidad Complutense, Madrid, 440 p, 14 làm.

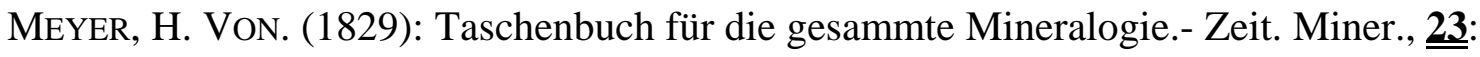
150-152.

Meyer, H. Von. (1833): Fossile Pferdeartige Thiere. - N. Acta Acad. Caes. Leopoldina, 16: 1-423.

Morales, J. (1984): Venta del Moro: su macrofauna de mamíferos y biostratigrafía continental del Mioceno terminal mediterráneo.- Editorial Universidad Complutense, Madrid, 340 pp.

Morales, J. \& Aguirre, E. (1976): Carnívoros de Venta del Moro. - Trabajos N-Q, $\underline{\underline{\mathbf{5}}}$ 31-81.

Morales, J., Soria, D. \& Aguirre, E. (1980): Camélido finimioceno en Venta del Moro. Primera cita para Europa Occidental. - Estudios Geol.., $\underline{\underline{36}}$ : 139-142.

Opdyke, N., Mein, P., Lindsay, E., Pérez GonzÁlez, A., Moissenet, E. \& Norton, V.L. (1997): Continental deposits, magnetostratigraphy and vertebrate paleontology, late Neogene of Eastern Spain. - Palaeogeogr., Palaeoclim., Palaeoec., 133: 129-148. Opdyke, N., Mein, P., Moissenet, E., Pérez González, A., Lindsay, E. \& Petko, M. (1990): The magnetic stratigraphy of the late Miocene sediments of the Cabriel Basin, Spain. - In: E.H. Lindsay, V. Fahlbusch, \& P. Mein (Eds.): European Neogene Mammal Chronology. - p. 507-514; Plenum Press, New York.

OWEN, R. (1848): Description of the teeth and portions of jaws of two extinct anthracotheroid quadrupeds discovered by the Marchioness of Hastings in the Eocene deposits of the N.W. coast of the Isle of Wight: with an attemp to develop Cuvier's idea of the classification of Pachyderms by the number of their toes.- Quart. J. geol. Soc. London, 노 : 103-141. 
Pesquero, M.D. (2003): Hipparion del Turoliense superior de Las Casiones (Fosa de Teruel). - Coloq. Paleontol., Vol. Extraord., 1: 511-548.

Pesquero, M.D., Alberdi, M.T. \& AlcalÁ, L. (2006): The late vallesian Hipparion from La Roma 2, Teruel, Spain: a study of the morphology and biometry variability of Hipparion primigenium. - J. Paleont., 으: 00-00.

Pickford, M., Morales, J. \& Soria, D. (1993): First fossil camels from Europe. Nature, $\underline{\underline{365}}$ : 701.

Pickford, M., Morales, J. \& Soria, D. (1995): Fossil camels from the Upper Miocene of Europe: implications for Biogeography and faunal change. - Geobios, $\underline{\underline{\mathbf{2 8}}}$ : 641-650.

PiRlOT, P.L. (1956) : Les formes européennes du genre Hipparion. - Mem. Com. Inst. Geol.., Diputación de la provincia de Barcelona, 14: 1-121.

QIU, Z., HuAnG, W. \& GuO, Z. (1987): The chinese Hipparionine fossils. - Paleont. Sinica, 175: 196-250.

Robles, F. (1974): Levante. - In: E. Aguirre \& J. Morales (Eds.): Coloquio Internacional sobre Biostratigrafía Continental del Neógeno Superior y Cuaternario Inferior. Libro-Guía. - p. 87-133; Madrid.

Robles, F., AcuñA, J.D., Gutiérrez, G. \& Nieto, M. (1983): Lugares de interés geológico de la provincia de Valencia.- Diputació Provincial de València, 127 pp.

Robles, F., Belinchón, M., García Flor, J. \& Morales, J. (1991): El Neógeno continental de Buñol y del valle del río Cabriel. - Rev. Española Paleont., $\mathrm{n}^{\mathrm{o}}$ Extraordinario: 205-215.

SondaAR, P. \& EISENMAnN, V. (1995): The Vertebrate Locality Maramena (Macedonia, Greece) at the Turolian-Ruscinian Boundary (Neogene). - Münchner Geowiss. Abh. (A), 28: 137-142.

VAN CAMPO, E. (1976): La flore sporopollinique du gisement Miocène terminal de Venta del Moro (Espagne).- Diplome d'Etudes Supérieures de Sciences Naturelles, Université des Sciences et Techniques du Languedoc, 54 pp., 39 pl.

VAN CAMPO, E. (1989): Flore pollinique du Miocène Supérieur de Venta del Moro (Espagne). - Acta Palynol., 1: 9-32.

Villalta, J.F. \& CRusafont, M. (1957): Dos nuevas especies de Hipparion del Pikermiense español. - Cur. Conf. Inst. Lucas Mallada, 4: 65-69. 
WooD, H.E. (1937): Perissodactyl suborders.- J. Mammal., 18: 106.

Woodburne, M.O., Bernor, R.L. \& Swisher, C.C.III (1996): An Appraisal of the Stratigraphic and Phylogenetic Bases for the "Hipparion" Datum in the Old World. - In: R.L. Bernor, V. Falbusch, \& H.W. Mittmann (Eds.): The Evolution of Western Eurasian Neogene Mammal Faunas. - p. 124-136; Columbia University Press, New York.

\section{Address of the authors}

María Dolores Pesquero [lolap@mncn.csic.es], Departamento de Paleobiología, Museo Nacional de Ciencias Naturales (CSIC), José Gutiérrez Abascal, 2, 28006 Madrid, Spain.

María Teresa Alberdi [malberdi@mncn.csic.es], Departamento de Paleobiología, Museo Nacional de Ciencias Naturales (CSIC), José Gutiérrez Abascal, 2, 28006 Madrid, Spain.

Plinio Montoya [pmontoya@uv.es] Departament de Geología, Àrea de Paleontología, Universitat de Valencia, Doctor Moliner, 50, 46100 Burjassot, Spain 


\section{Table Captions}

Table 1. Hypsodonty index of the Spanish Hipparion.

Table 2. Dimensions in millimetres of the Venta del Moro Hipparion lower and upper cheek teeth. Abbreviations: P/p: upper and lower premolars; M/m: upper and lower molars. Nomenclature following EISENMANN et al. (1988).

Table 3. Dimensions in millimetres of the Venta del Moro Hipparion 1PhIII, Astragalus, McIII and MtIII. Nomenclature same as in Table 2.

Table 4. Gracility index of the Spanish, Asian and African Hipparion.

Table 5. Homogeneus subsets calculated by Tukey's HSD test $(\mathrm{p}<0.05)$ showing the significant differences among Ast., 1PhIII, McIII and MtIII from VM, KS, ML, PAV, SA, SH, CG and HO.

Table 6. Most influential characters for component 1 (corresponds to size) and component 2 (corresponds to length) in the Principal Component Analysis (PCA).

Table 7. Percentage correct classification by cross-validation techniques. 1: Hipparion matthewi (VM + KS + PAV + SH + SA); 2: Hipparion matthewi ssp. (ML + VM); 3: Hipparion concudense (CG); 4: Hipparion primigenium (HO).

\section{Figure Captions}

Figure 1. Geographic distribution of the localities. 1, Venta del Moro; 2, Teruel area: Cerro de la Garita (Concud) (CG), Las Casiones (KS), El Arquillo (ARQ) and Milagros (ML), 3 Pavlodar (PAV), 4 Samos (SA), 5 Sahabi (SH), 6 Höwenegg (HO).

Figure 2. Morphological characters of the upper (top) and lower (bottom) cheek teeth of Hipparion.

Figure 3. Hipparion from Venta del Moro (Valencia, Spain). $\underline{\underline{\text { A-B. }} . ~ H i p p a r i o n ~ m a t t h e w i ~}$ Villalta \& Crusafont, 1957. $\underline{\underline{\mathbf{A}} .}$ VV-7859, left maxilar with P2-M3. $\underline{\underline{\mathbf{B}} .}$ VV-819, 
right maxilar with P2-M3. $\underline{\underline{\text { C-E. }} . ~ H i p p a r i o n ~ p r i m i g e n i u m ~ V . M E Y E R, ~ 1829 . ~ C . ~ V V-4699, ~}$ left P3-4. ‥ VV-1591, right P3-4. E. MNCN-11307, right P3-4: in section ( $\left.\mathrm{E}_{1}\right)$, and in

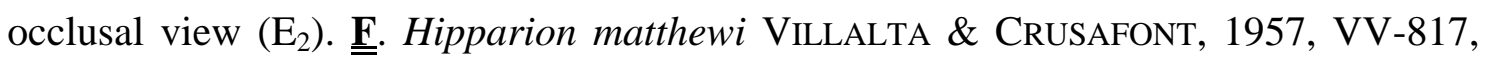
mandible in lateral view $\left(\mathrm{F}_{1}\right)$, and in occlusal view $\left(\mathrm{F}_{2}\right)$. $\underline{\underline{\mathbf{G}}}$. Hipparion primigenium V.MEYER, 1829, MNCN-10982, right m1-2. Scale bar is $20 \mathrm{~mm}$.

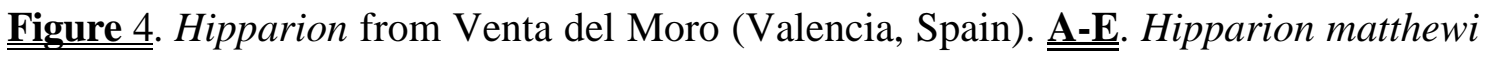
Villalta \& Crusafont, 1957. $\underline{\underline{\mathbf{A}}}$. VV-3171, left McIII. $\underline{\underline{\mathbf{B}} .}$ VV-7211, right MtIII. $\underline{\underline{\mathbf{C}}}$. VV-699, right MtIII. $\underline{\underline{\mathbf{D}}}$ VV-8287, right McIII. $\underline{\underline{\mathbf{E}} .}$ VV-5358, left calcaneus. $\underline{\underline{\mathbf{F}}}$.

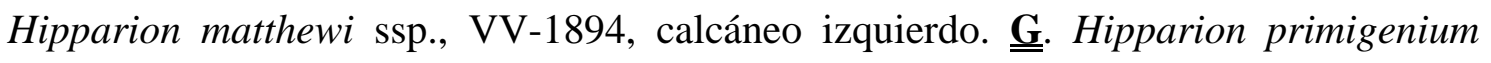
V.MeYeR, 1829, VV-696, right astragalus. $\underline{\underline{\mathbf{H}}}$. Hipparion matthewi ViLLALTA \& CRUSAFONT, 1957, VV-8291, left astragalus. $\underline{\underline{\mathbf{I}-K}}$. Hipparion matthewi ssp. $\underline{\underline{\mathbf{I}} .}$ VV-3304,

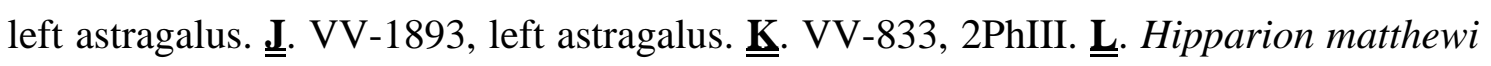
Villalta \& CRUSAFONT, 1957, VV-7728, 2PhIII. Scale bar is $30 \mathrm{~mm}$.

Figure 5. Occlusal length vs occlusal breadth plotted for the upper and lower cheek teeth (p3-4, m1-2, P3-4 and M1-2) of Spanish and Asiatic Hipparion localities. 95\% confidence interval ellipses superimposed. Continuous line for $H$. primigenium, dashed line for $H$. matthewi, and dotted line for $H$. periafricanum.

Figure 6. Scatter diagram of the McIII and MtIII (dimension 1 vs dimension 3, and dimension 1 vs. dimension 11) of Spanish and Asiatic Hipparion localities. 95\% confidence interval ellipses superimposed. Continuous line for $H$. primigenium, dashed line for $H$. matthewi, and dotted line for $H$. periafricanum.

Figure 7. Scatter diagram of the 1PhIII (dimension 1 vs dimension 3) of Spanish and Asiatic Hipparion localities. 95\% confidence interval ellipses superimposed. Continuous line for $H$. primigenium, dashed line for $H$. matthewi, and dotted line for $H$. periafricanum.

Figure 8. Principal component analysis of the distribution of Spanish and Asiatic Hipparion localities using the McIII. The parameters used follow the "Hipparion Conference” recommendations (EISENMANN et al. 1988).

Figure 9. Principal component analysis of the distribution of Spanish and Asiatic Hipparion localities using the MtIII. The nomenclature of the parameters same as in figure 7. 
Figure 10. Principal component analysis of the distribution of Spanish and Asiatic Hipparion localities using the astragalus. The nomenclature of the parameters same as in figure 7.

Figure 11. Principal component analysis of the distribution of Spanish and Asiatic Hipparion localities using the first phalanx III. The nomenclature of the parameters same as in figure 7.

Figure 12. Discriminant analysis based on the PCA results (see Fig.7) of the McIII of Spanish, and Asiatic Hipparion localities.

Figure 13. Discriminant analysis based on the PCA results (see Fig.8) of the MtIII of Spanish and Asian Hipparion localities.

Figure 14. Discriminant analysis based on the PCA results (see Fig. 9) of the astragalus of Spanish and Asian Hipparion localities.

Figure 15. Discriminant analysis based on the PCA results (see Fig.10) of the first phalanx III of Spanish and Asian Hipparion localities. 
Figure 1

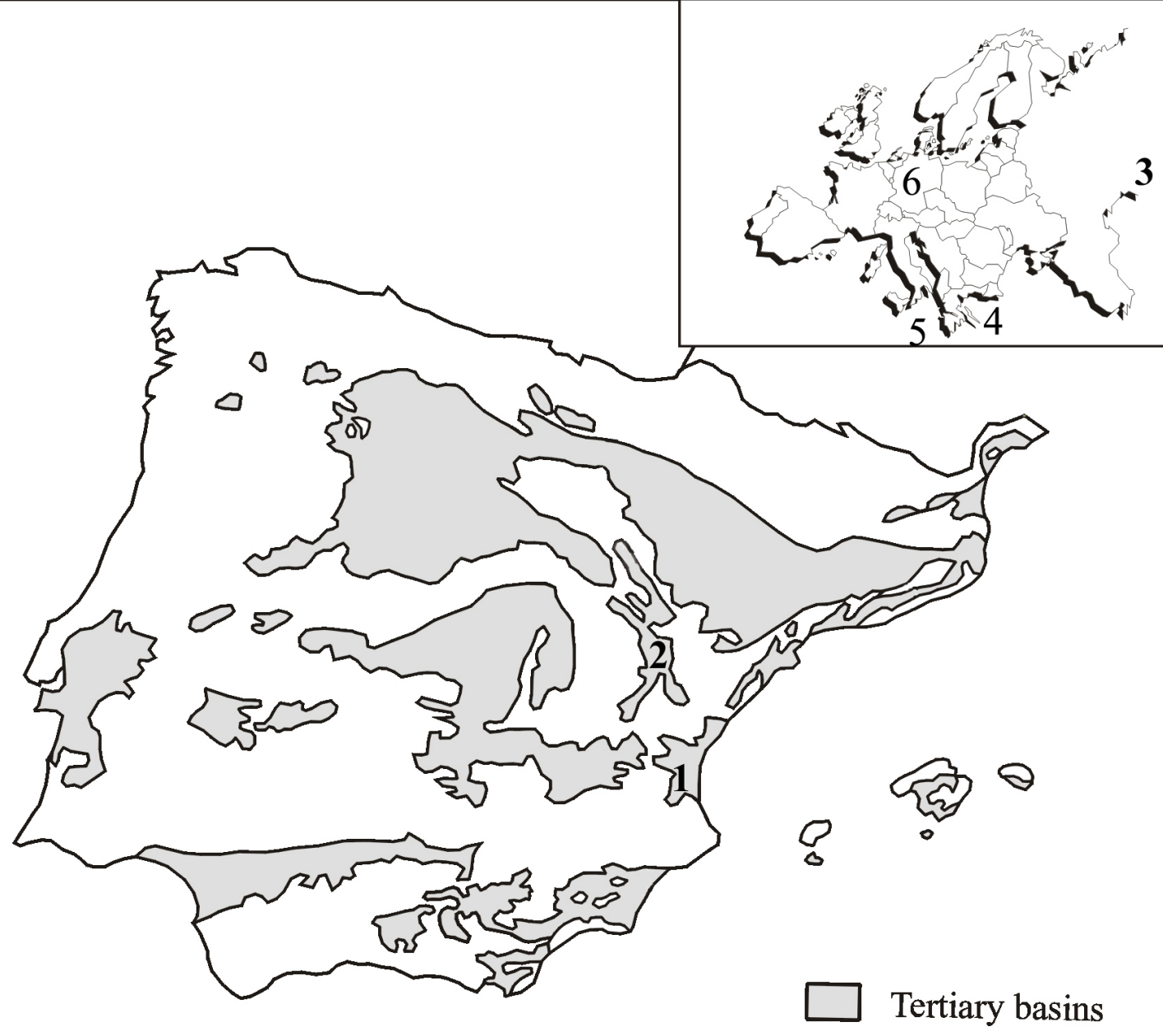


Figure 2

\section{BUCCAL}

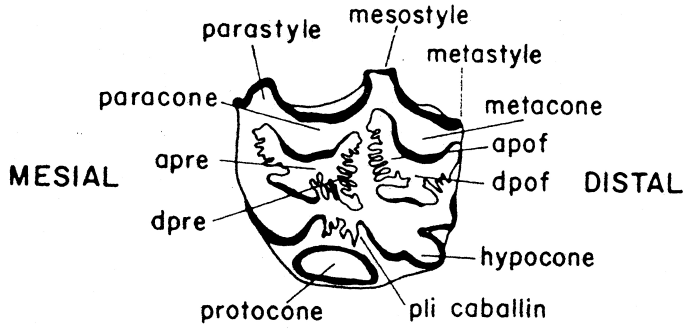

LINGUAL

LINGUAL

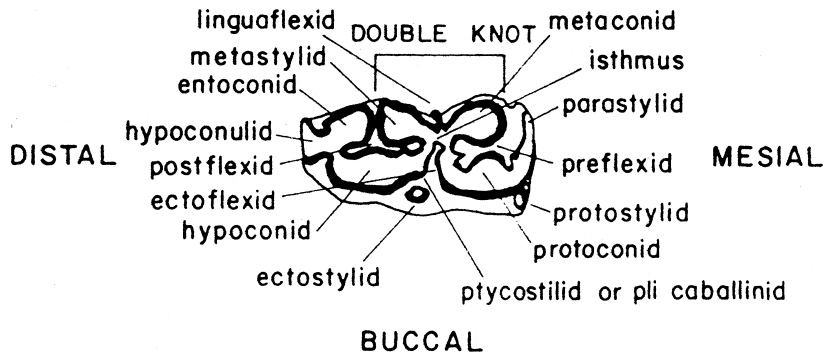



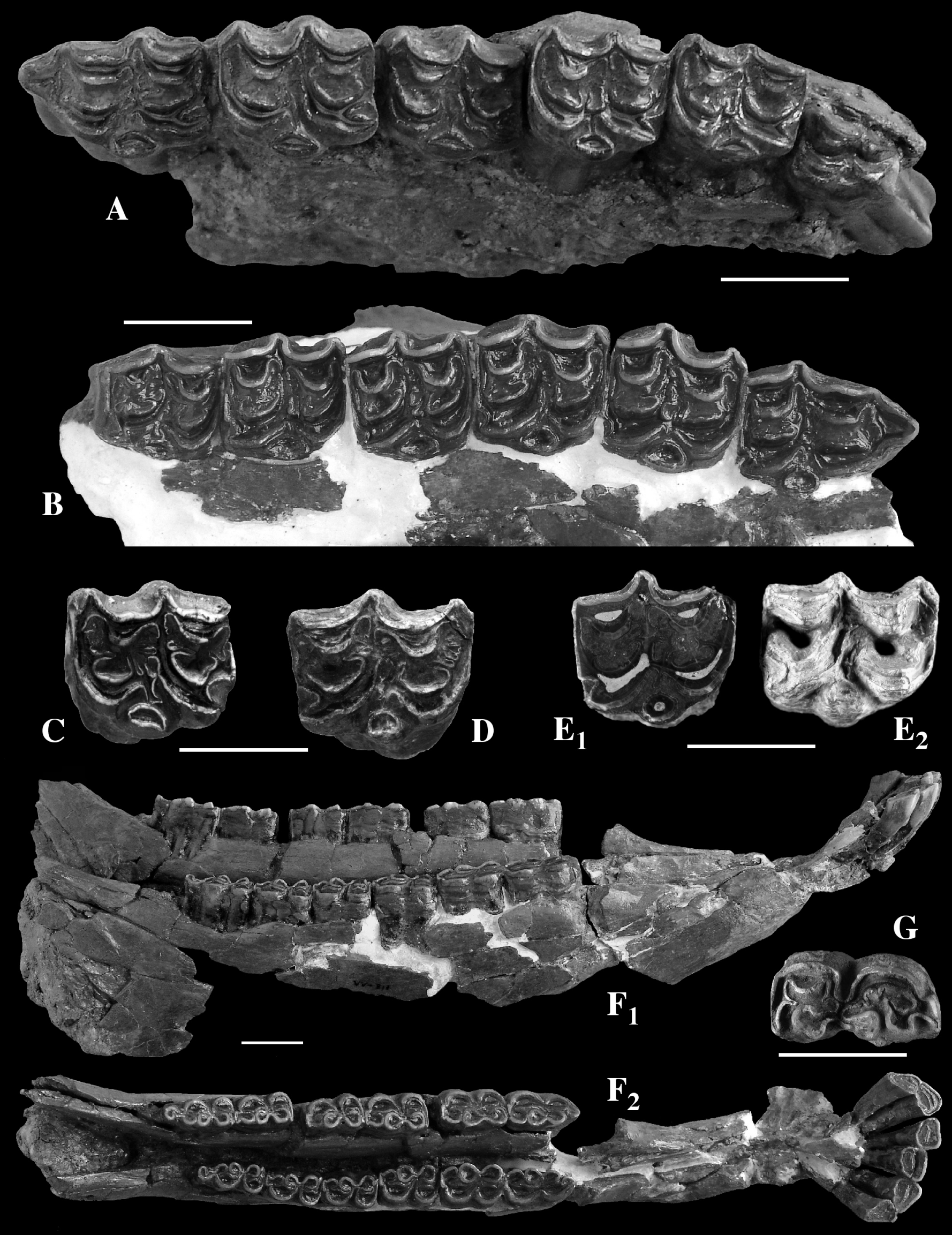


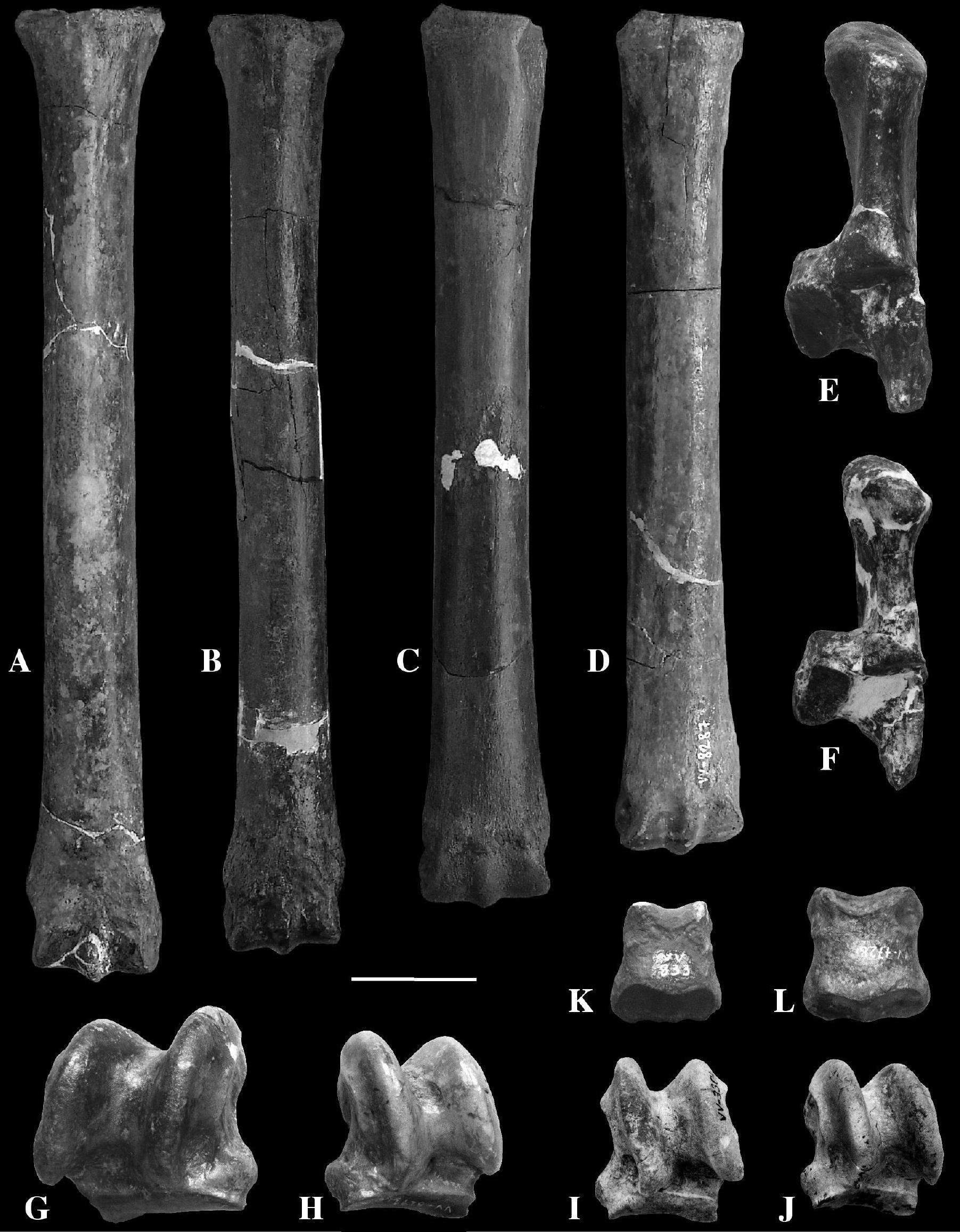




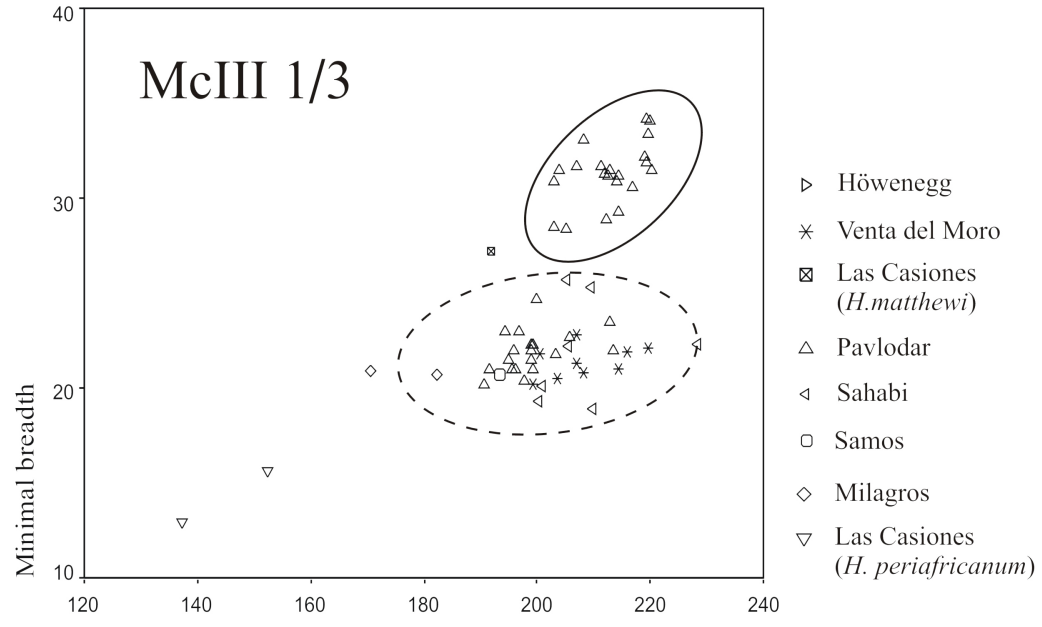

Maximal length

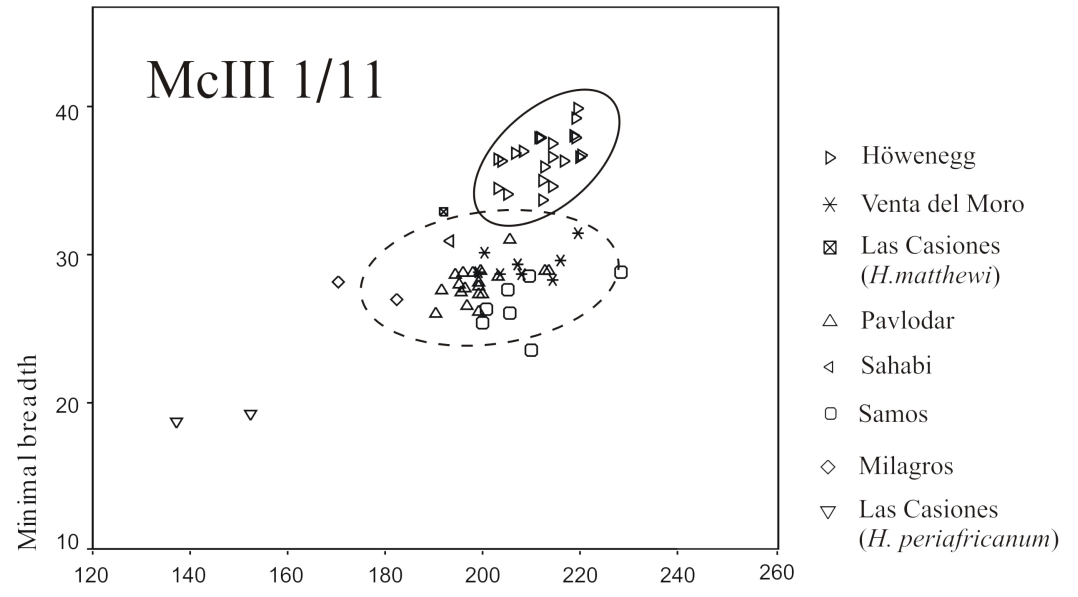

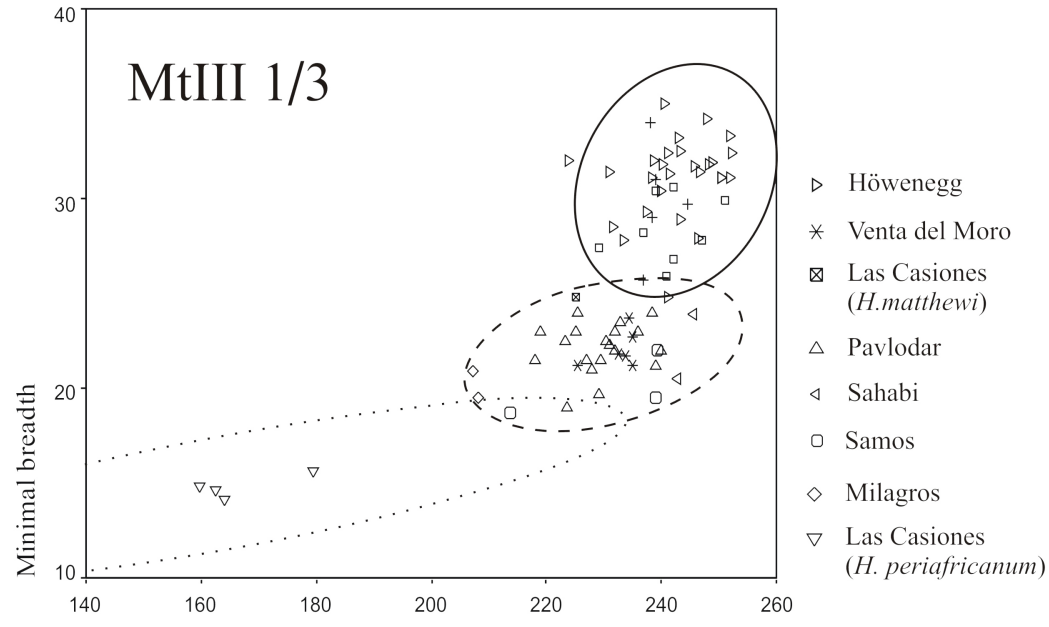

Maximal length

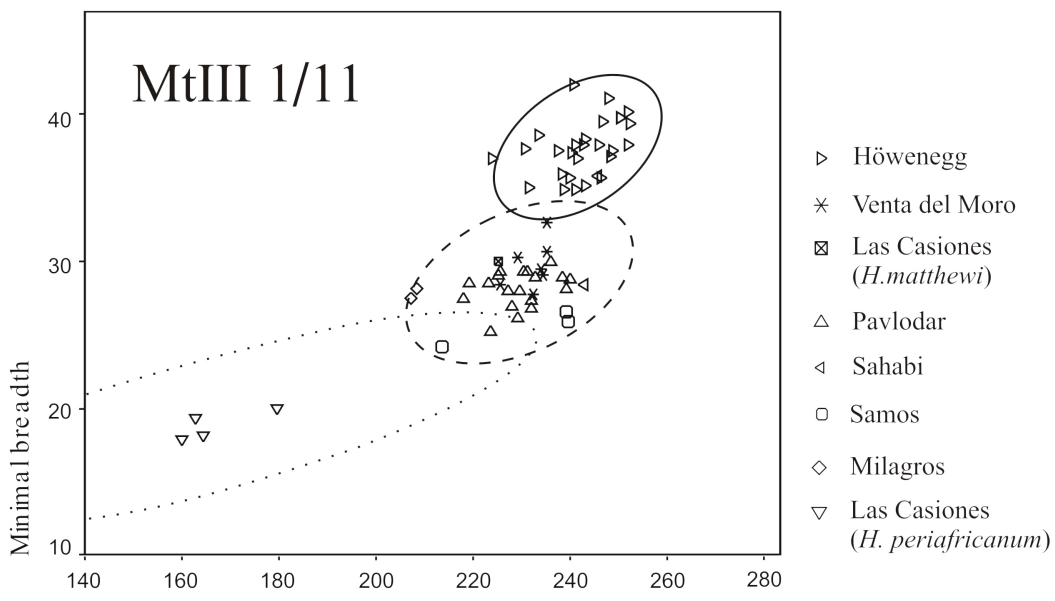


Figure 8

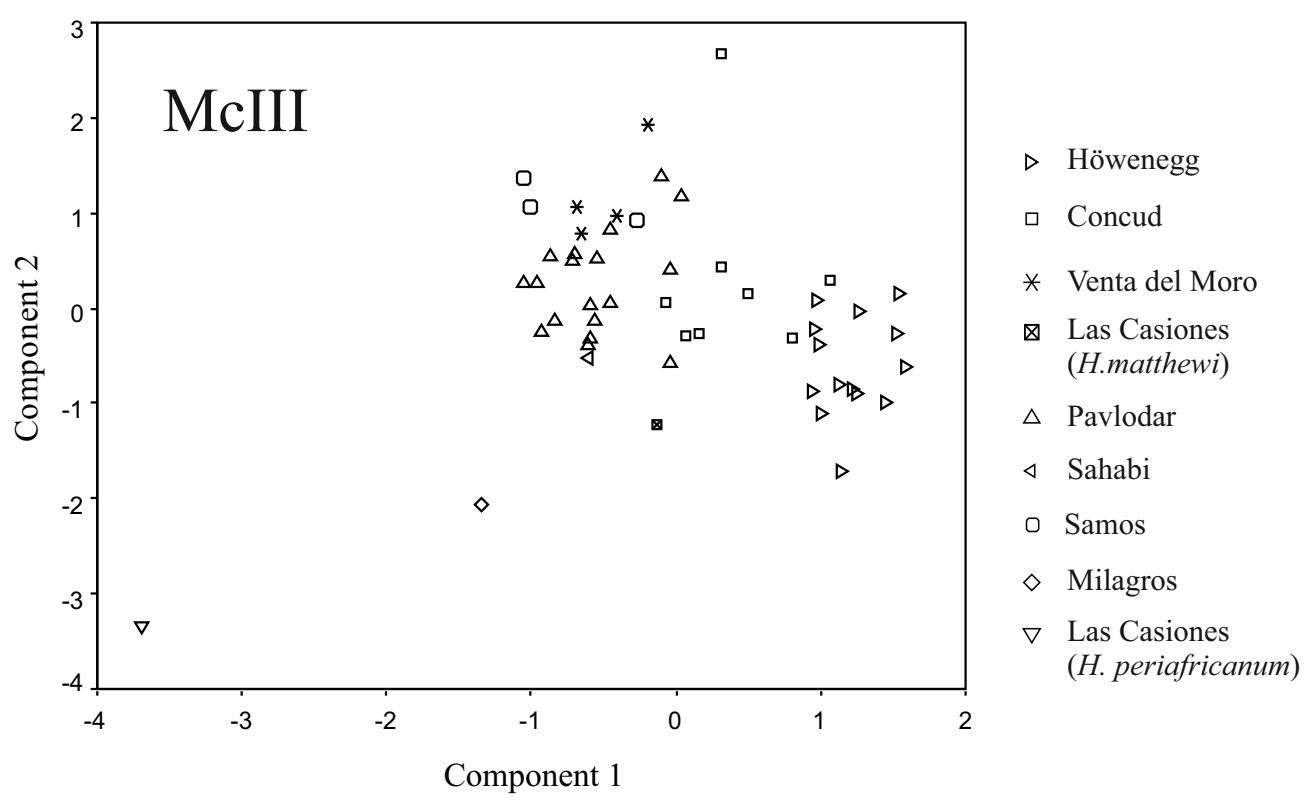


Figure 9

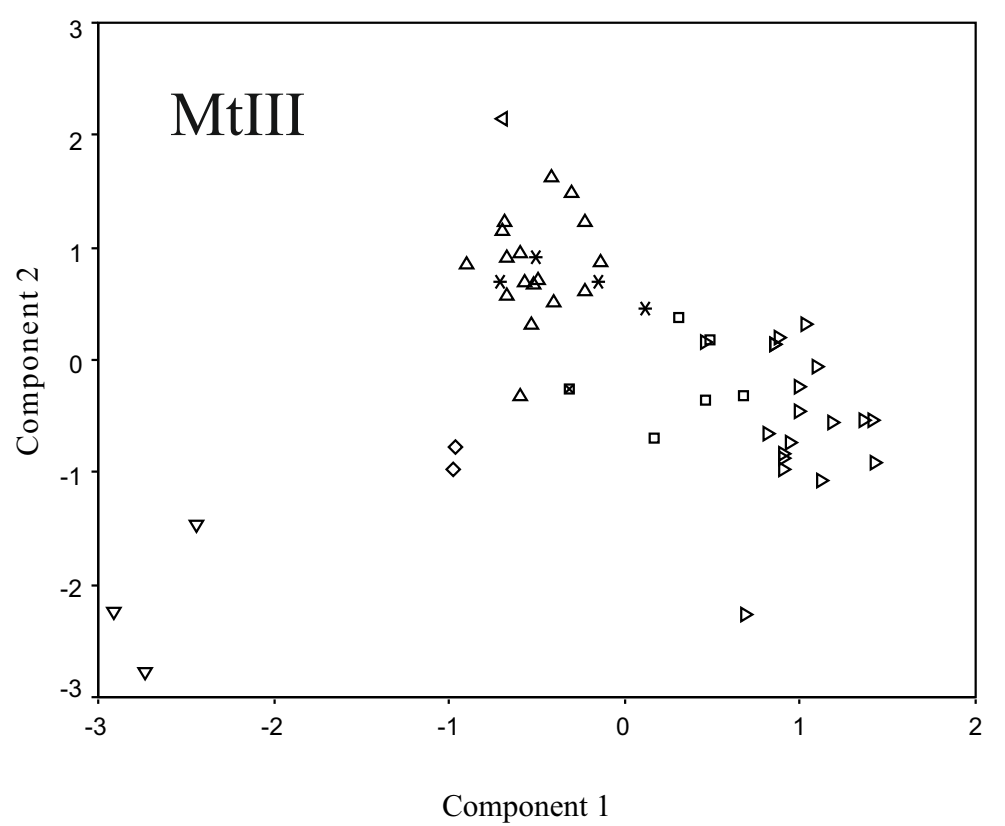

\ Höwenegg

Concud

* Venta del Moro

凶 Las Casiones (H.matthewi)

$\triangle$ Pavlodar

$\triangleleft$ Sahabi

$\diamond$ Milagros

$\nabla \quad$ Las Casiones (H. periafricanum)

Component 1 
Figure 10

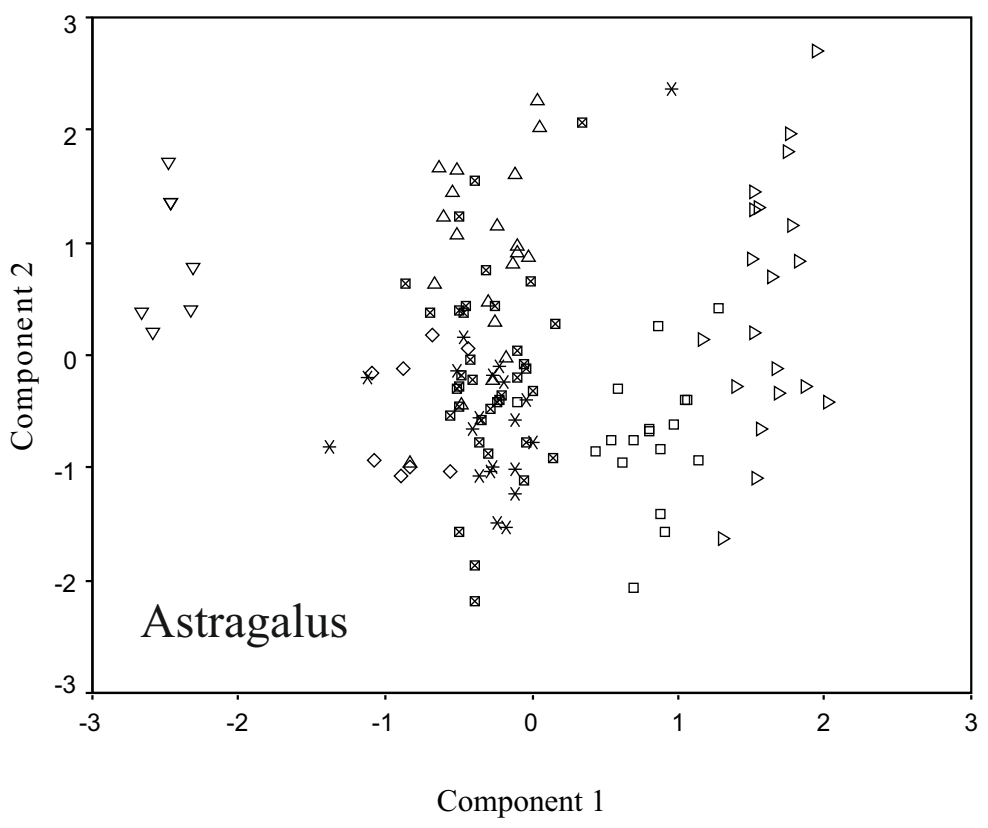

$\triangleright$ Höwenegg

- Concud

* Venta del Moro

凶 Las Casiones (H.matthewi)

$\triangle$ Pavlodar

$\diamond$ Milagros

$\nabla$ Las Casiones (H. periafricanum) 
Figure 11

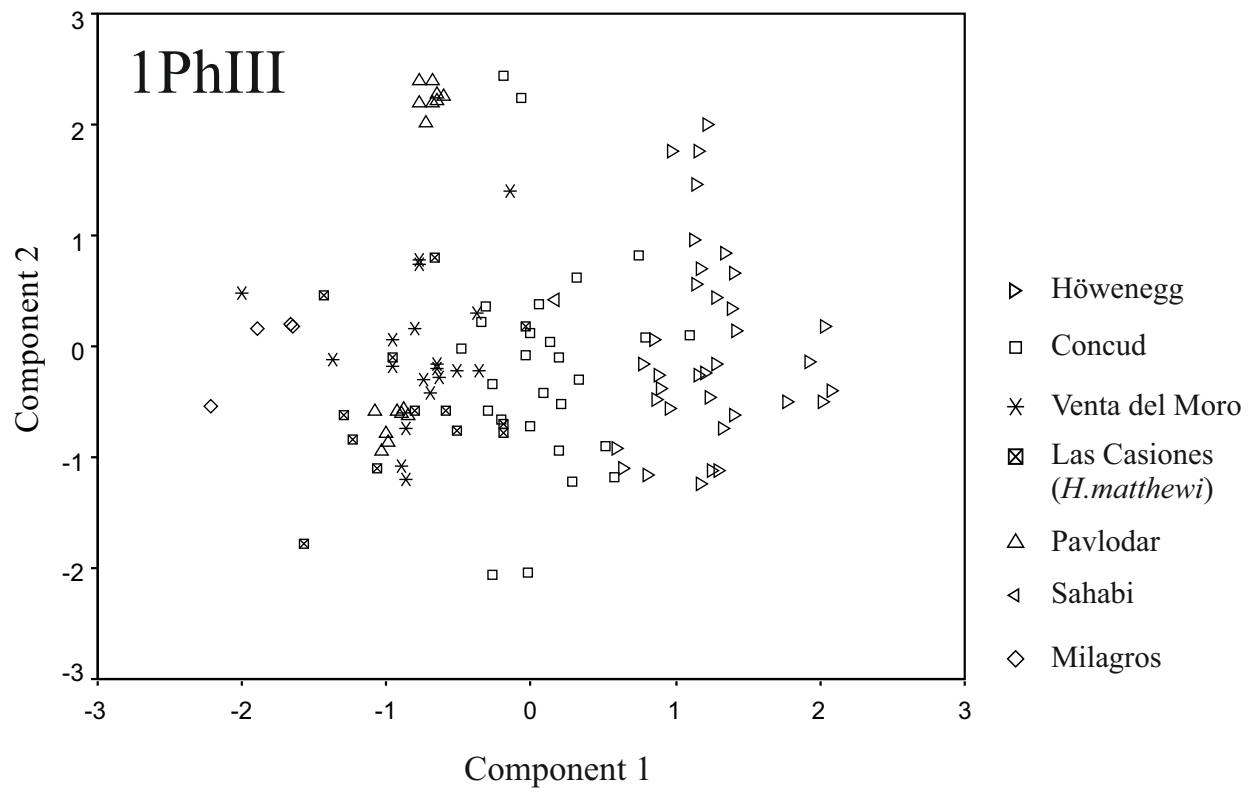


Figure 12

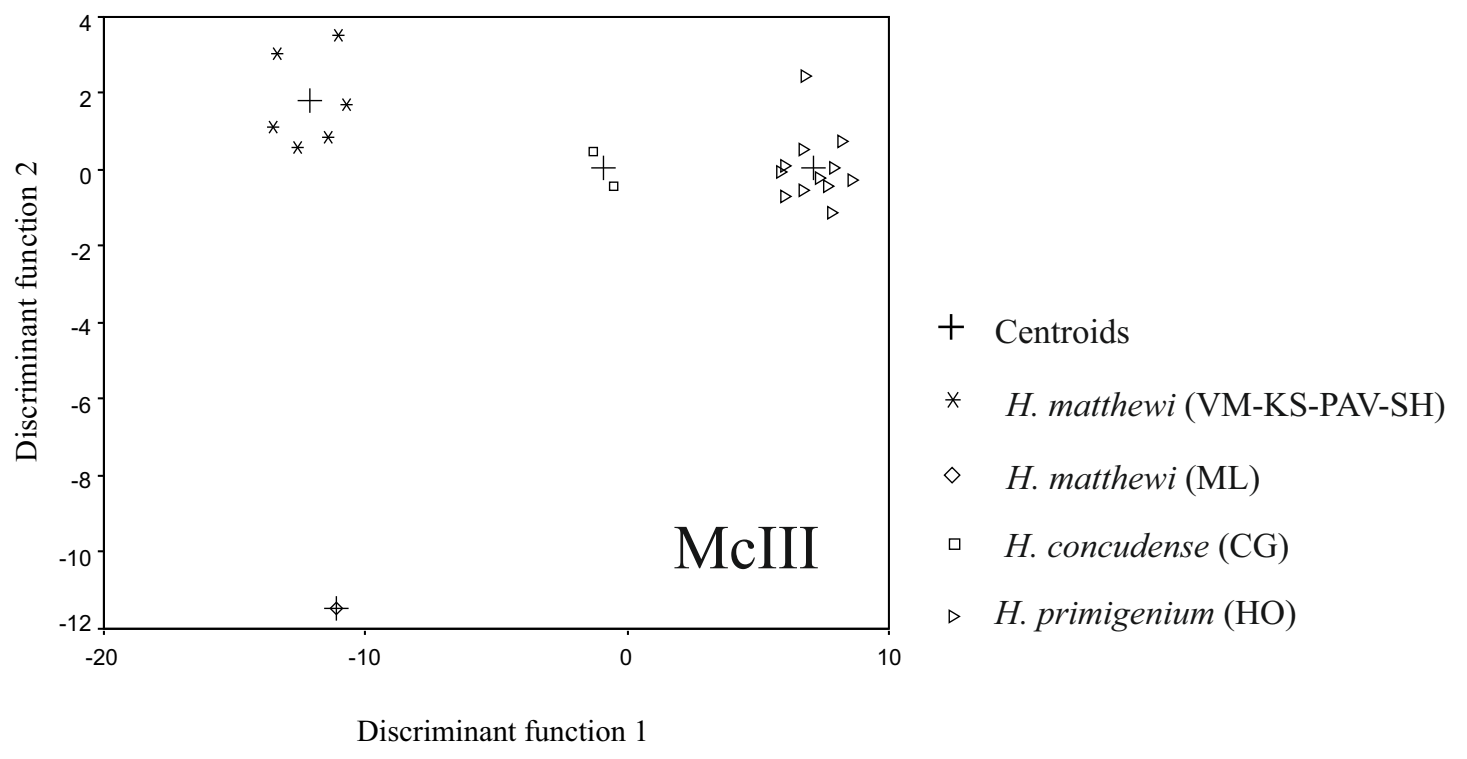


Figure 13

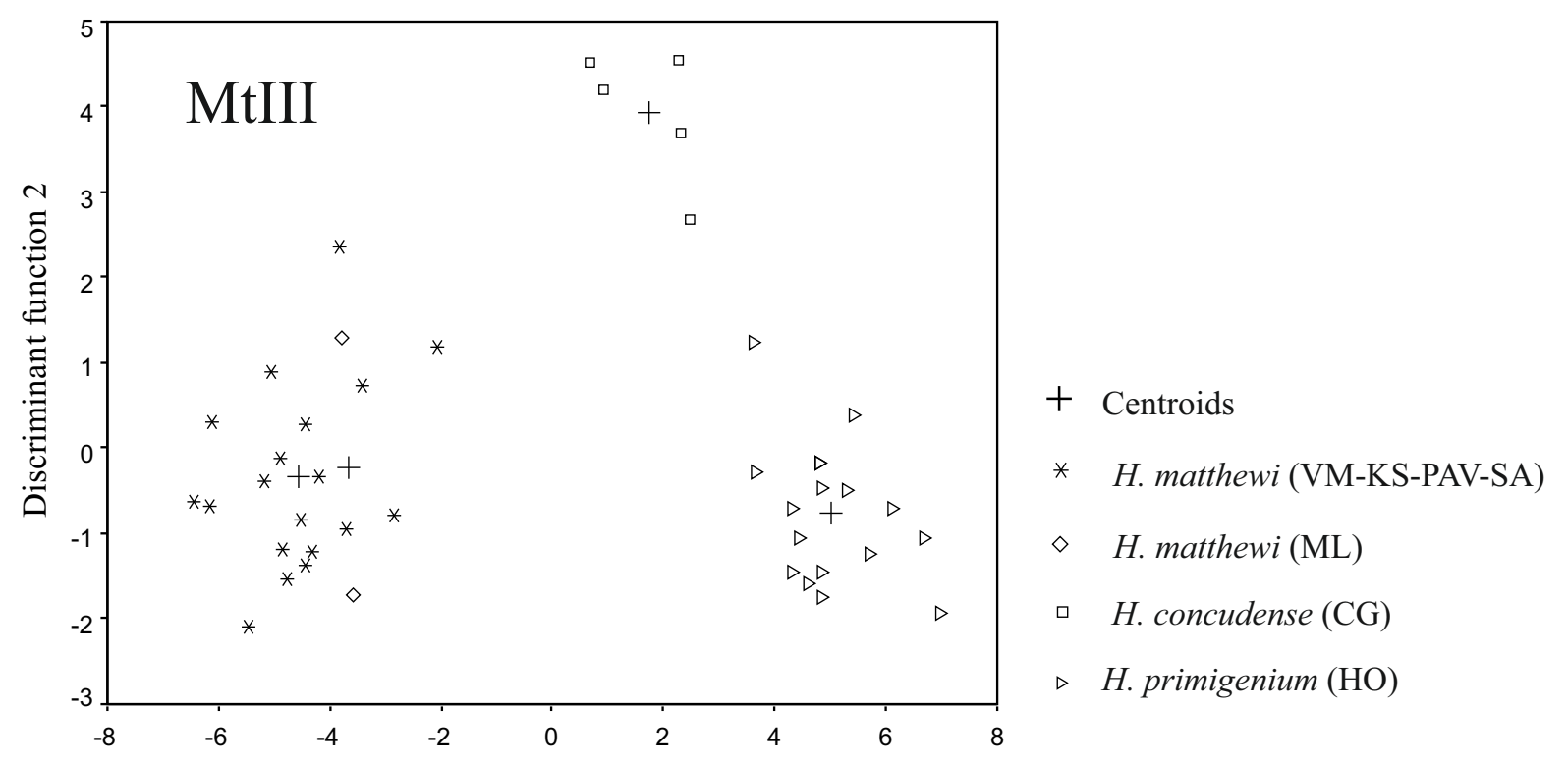

Discriminant function 1 
Figure 14

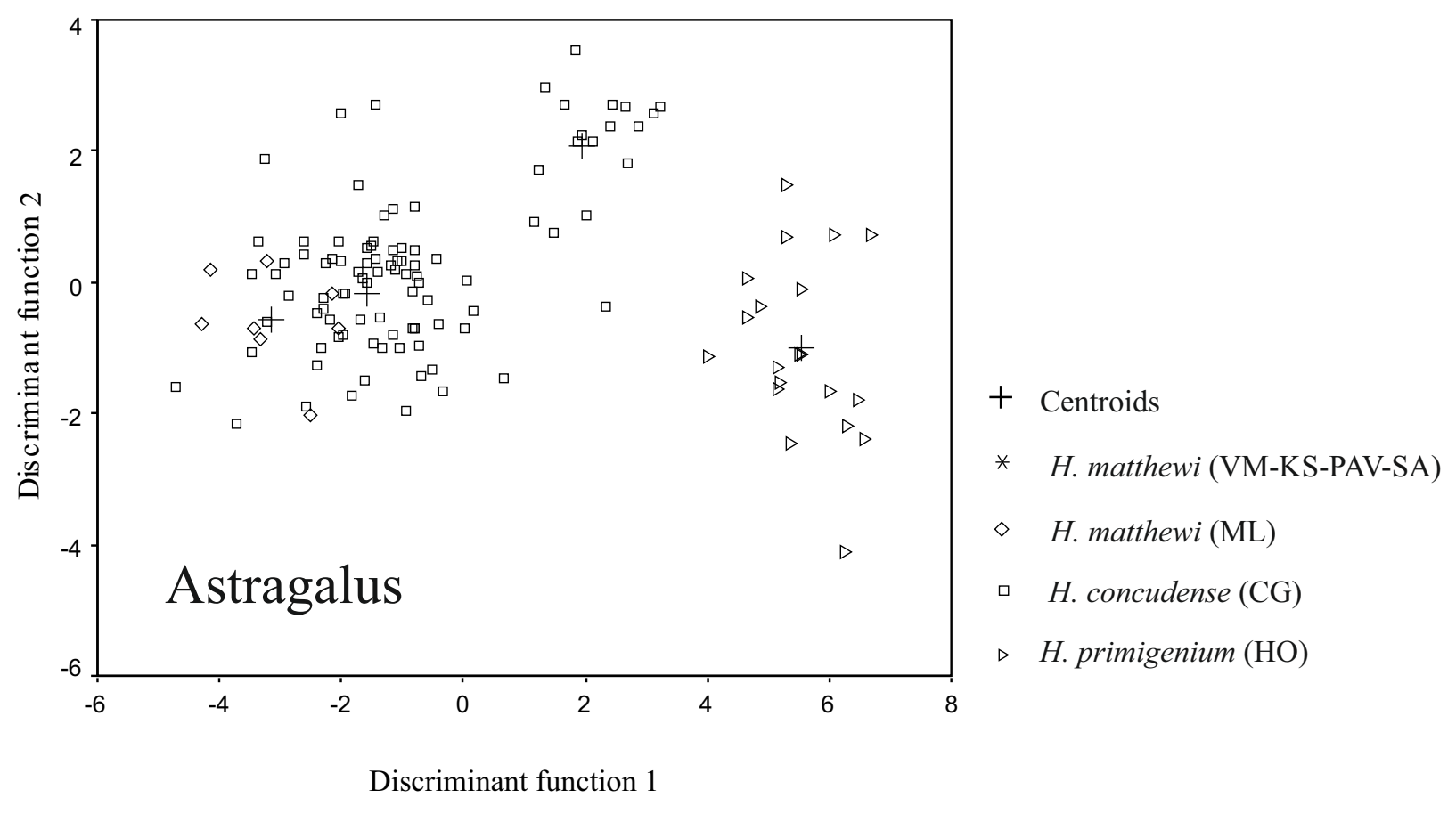


Figure 15

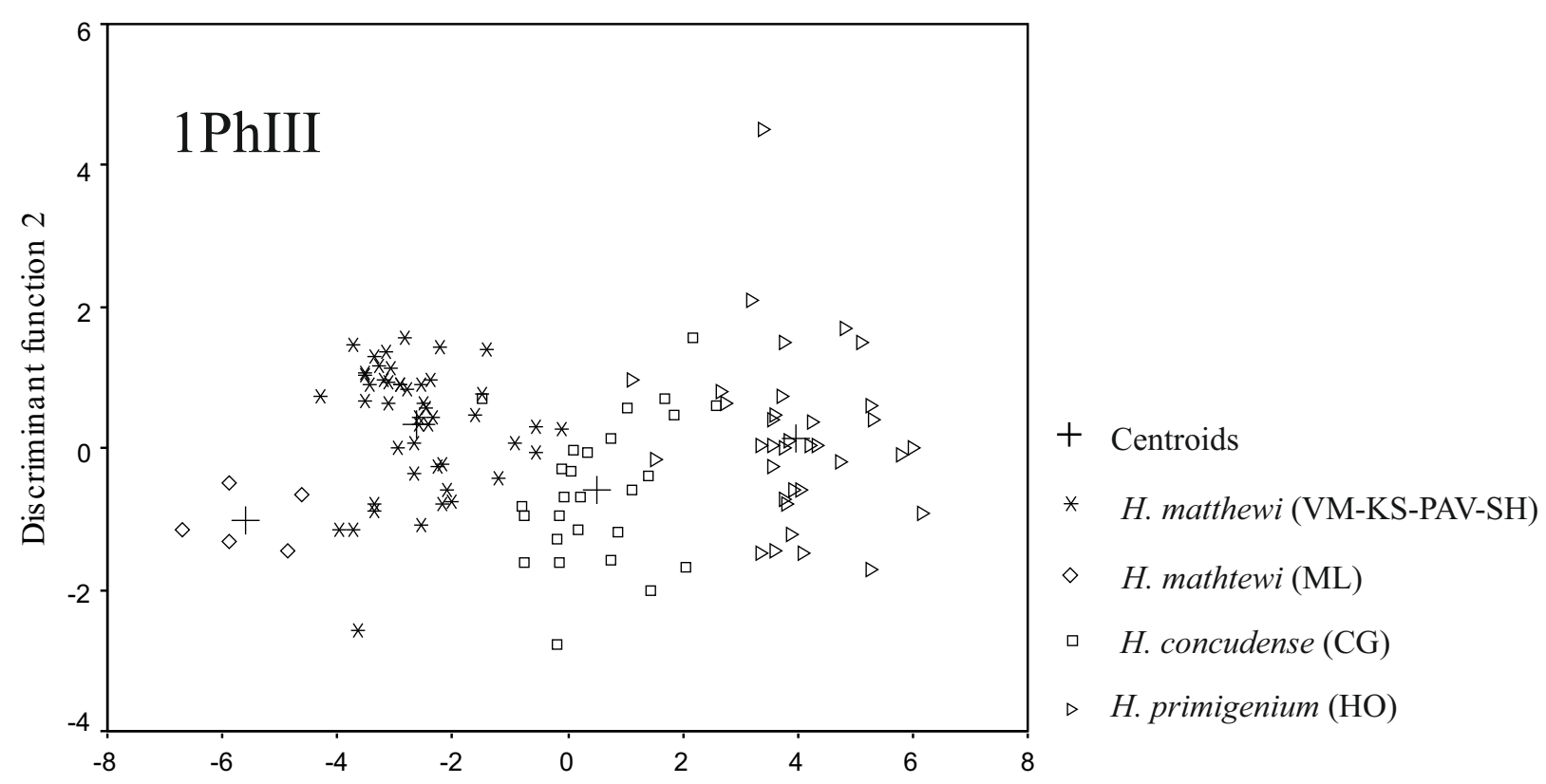

Discriminant function 1 


\section{Figure 7}
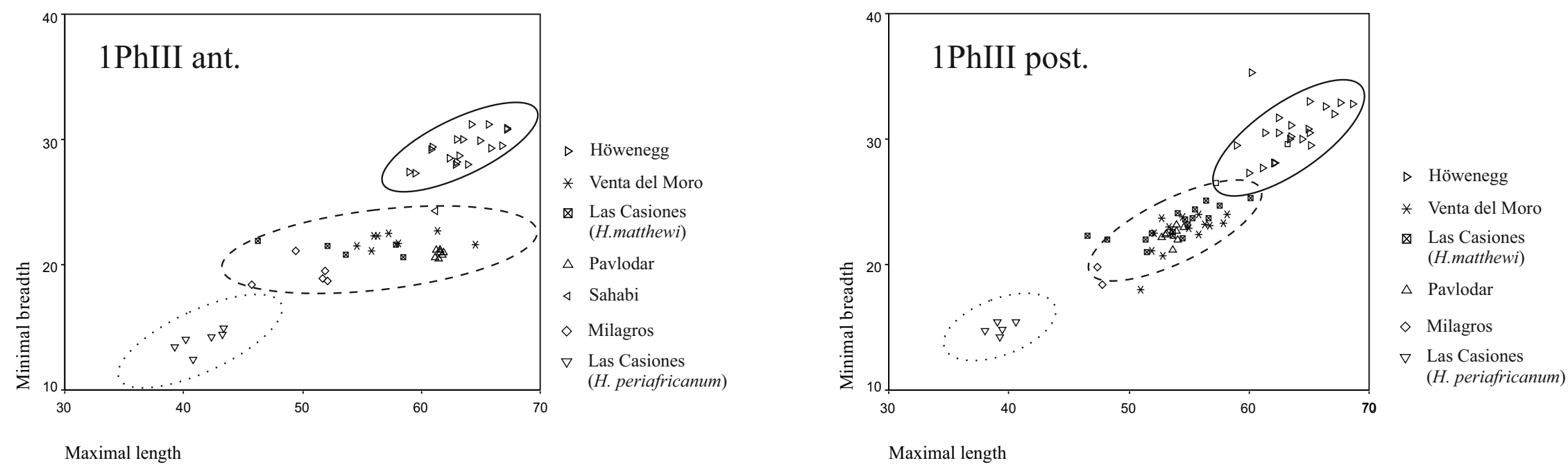
Table 1

\section{HIPSODONTY INDEX}

\begin{tabular}{|c|c|c|c|c|c|c|c|c|c|c|c|}
\hline & \multicolumn{3}{|c|}{ H. concudense (CG) } & \multicolumn{3}{|c|}{ H. matthewi (KS) } & \multicolumn{3}{|c|}{ H. matthewi (ARQ) } & \multicolumn{2}{|c|}{ H. periafrica } \\
\hline & $\mathbf{N}$ & D.est & $\mathrm{X}$ & $\mathbf{N}$ & D.est & $\mathrm{x}$ & $\mathbf{N}$ & D.est & $\mathrm{X}$ & $\mathbf{N}$ & D.est \\
\hline P3-4 & (13) & 0,13 & 2,5 & (3) & 0,11 & 2,5 & (3) & 0,1 & 2,7 & (2) & 0,13 \\
\hline M1-2 & (19) & 0,12 & 2,6 & $(17)$ & 0,16 & 2,7 & (10) & 0,11 & 2,8 & (7) & 0,14 \\
\hline p3-4 & (16) & 0,09 & 2,4 & $(2)$ & 0,16 & 2,3 & (1) & - & 2,7 & (2) & 0,02 \\
\hline m1-2 & (19) & 0,12 & 2,6 & (14) & 0,18 & 2,7 & (3) & 0,05 & 2,8 & (5) & 0,04 \\
\hline
\end{tabular}




\begin{tabular}{c|ccc}
\hline num (KS) & \multicolumn{3}{|c}{ Hipparion (VM) } \\
$\mathbf{X}$ & $\mathbf{N}$ & D.est & $\mathbf{X}$ \\
\hline & & & \\
2,9 & $(1)$ & - & 2,5 \\
3,2 & $(9)$ & 0,04 & 2,4 \\
2,8 & $(1)$ & - & 2,5 \\
3,1 & $(5)$ & 0,16 & 2,7 \\
\hline
\end{tabular}


Table 2

\begin{tabular}{|c|c|c|c|c|c|c|c|}
\hline & & 1 & 2 & 3 & 4 & 5 & 6 \\
\hline \multirow[t]{21}{*}{ P2 } & VV3298 & 31,4 & 6 & 22 & 31,3 & 21,4 & 28,5 \\
\hline & VV3318 & 31,4 & 6 & 22 & 31,2 & 20,3 & 30,2 \\
\hline & VV4622 & 32 & 7,2 & 18,9 & 30,9 & 21,6 & 43,3 \\
\hline & VV809 & 31,2 & 6 & 22 & 30,2 & 20,7 & 33,8 \\
\hline & VV4555 & 30,2 & 7,1 & 21,6 & 28,8 & 21,3 & 30,5 \\
\hline & VV3960 & 30,8 & 6,5 & 21,8 & 28,3 & 22,1 & 30,4 \\
\hline & VV810 & 28,3 & 6,9 & 19,6 & 27,2 & 18,6 & 20 \\
\hline & VV3202 & 29,3 & 6,2 & 20,5 & 29,4 & 19,1 & 22,7 \\
\hline & VV2576 & 28,9 & 5,6 & 20,4 & 27,7 & 19,3 & 21,5 \\
\hline & VV3324 & 32,4 & 6,2 & 22,4 & 0,29 & 20,1 & 35,6 \\
\hline & VV3130 & 30,5 & 6,4 & 20,2 & 28,5 & 18,9 & 36,8 \\
\hline & VV3727 & 30,8 & 6,2 & 20,9 & 30,1 & 20,1 & 24,6 \\
\hline & VV3547 & 30 & 7,3 & 20,5 & 29,1 & 20,2 & 14,8 \\
\hline & VV3003 & - & 5,9 & - & - & - & 23,8 \\
\hline & VV3325 & 31,1 & 6,6 & 21,6 & 27,8 & 21,2 & 32,5 \\
\hline & VV4358 & 30 & 7,1 & 19,6 & 28,8 & - & 28,4 \\
\hline & VV4576 & 30,5 & 7,8 & 19,7 & 28,5 & 18,5 & 37,8 \\
\hline & VV538 & 26,7 & 7 & 21,1 & - & - & 15,7 \\
\hline & VV605 & 29,4 & 6,4 & 21,2 & - & - & 15,7 \\
\hline & VV819 & 28,2 & 6,4 & 21,2 & - & - & 23,8 \\
\hline & VV819 & 28,8 & 6,7 & 20,8 & - & - & 24,3 \\
\hline \multirow[t]{34}{*}{ P3-4 } & VV4325 & 26,2 & 7,8 & 22,9 & 21,8 & 21,6 & 39,5 \\
\hline & VV4602 & - & - & - & 23 & 22,7 & - \\
\hline & VV3266 & 24,8 & 7,3 & 21,7 & 21,3 & 20,5 & 41,6 \\
\hline & VV3477 & 24,8 & 6,2 & 23,7 & 21,9 & 21,9 & 33,3 \\
\hline & VV3984 & 25,4 & 7,3 & 22,9 & 0,22 & 22,6 & 34,4 \\
\hline & VV1591 & 30 & 5,6 & 23,1 & 25,4 & 24,9 & 33,5 \\
\hline & VV2690 & 24,7 & 7,6 & 21,6 & 21,2 & 20,5 & 43,9 \\
\hline & VV284 & 22,9 & 8,2 & 21,9 & 20,5 & 20,2 & 33,9 \\
\hline & VV845 & 23,9 & 5,8 & 22,8 & 22,2 & 21,3 & 28,7 \\
\hline & VV4699 & 25,6 & 6,6 & 23,2 & 22,7 & 25,2 & 38,9 \\
\hline & VV3907 & 23,1 & 5,3 & 22,3 & 20,7 & 21,7 & 21,1 \\
\hline & VV3985 & 22,3 & 5,8 & 21,3 & 20 & 20,5 & 28,4 \\
\hline & VV3409 & 24,2 & 6 & 21,9 & 20,1 & 19,6 & 40,5 \\
\hline & VV3168 & 21,8 & 6,2 & 22,3 & 20,2 & 21,7 & 23,6 \\
\hline & VV799 & 21,5 & 5,4 & 20,7 & 19,2 & 20,6 & 28,5 \\
\hline & VV2769 & 21,7 & 6,5 & 21,5 & 20,7 & 22,1 & 26,8 \\
\hline & VV2561 & 22,7 & 5,6 & 21,9 & 20,8 & 20,1 & 23 \\
\hline & VV2911 & 22 & 5,6 & 21,2 & 19,1 & 19,9 & 26,8 \\
\hline & VV837 & 23,2 & 6,8 & 23 & 20,9 & 21 & 21,2 \\
\hline & VV3223 & 23 & 6,5 & 21,1 & 20,9 & 21 & 21,2 \\
\hline & VV3887 & 19,7 & 5,5 & 19,9 & 18,4 & 18,9 & 22,9 \\
\hline & VV3671 & 21 & 6,3 & 20,9 & 20 & 20,6 & 18 \\
\hline & VV448 & 22 & 5,8 & 21,2 & 20,9 & 21,3 & 25,9 \\
\hline & VV84 & 22,6 & 6,2 & 22 & 21,6 & 21,2 & 16 \\
\hline & VV3260 & 20,5 & 6,3 & 20,4 & 20,8 & 20,5 & 0,18 \\
\hline & VV3624 & 20,1 & 6,8 & 21,4 & 20,1 & 21,4 & 10,3 \\
\hline & VV1114 & 20 & 6,9 & 21,3 & 0,2 & 21 & 11,4 \\
\hline & VV2198 & 19,9 & 6,8 & 21,8 & 19,9 & 21,8 & 10,8 \\
\hline & VV807 & 18,9 & 6 & 20,7 & 18,9 & 20,7 & 9,6 \\
\hline & VV3329 & 19,2 & 6,4 & 19,8 & 19,2 & 19,8 & 8,3 \\
\hline & VV1084 & 20,4 & 6,4 & - & 20,4 & - & 8,9 \\
\hline & VV3216 & 19,9 & 5,8 & 20,6 & 19,9 & 20,6 & 7,6 \\
\hline & VV4574 & 18,3 & - & 21,7 & 18,3 & 21,7 & 6,6 \\
\hline & VV803 & 21,1 & 6 & 22,3 & 20,5 & 20,5 & 15,4 \\
\hline
\end{tabular}




\begin{tabular}{|c|c|c|c|c|c|c|c|}
\hline & & 1 & 2 & 3 & 4 & 5 & 6 \\
\hline \multirow[t]{7}{*}{ P3-4 } & VV1572 & 20,7 & 5,9 & 22,1 & 20,5 & 21,9 & 17,5 \\
\hline & VV2758 & 20,4 & 6,1 & 22,4 & 20,3 & 21,5 & 15,9 \\
\hline & VV2577 & 20,4 & 6,1 & 22,4 & 19,6 & 21,4 & 10,9 \\
\hline & VV1606 & 21,6 & 5,5 & 21,5 & - & - & - \\
\hline & VV819 & 21,4 & 6,5 & 22,8 & - & - & - \\
\hline & VV819 & 21 & 6,7 & 22,4 & - & - & - \\
\hline & VV819 & 20,9 & 6,3 & 0,22 & - & - & - \\
\hline \multirow[t]{38}{*}{ M1-2 } & VV2108 & 23,9 & 7,5 & 20,2 & 19,6 & 20,6 & 45,5 \\
\hline & VV3012 & 24,2 & 7,6 & 19,7 & 20,3 & 20,7 & 48,1 \\
\hline & VV3364 & 24,7 & 8,1 & 19,8 & 19,4 & 20,2 & 46,7 \\
\hline & VV3878 & 22,4 & 7,9 & 18,2 & 19,1 & 19,2 & 46,8 \\
\hline & VV5266 & 24,4 & 7,7 & 21,8 & 21,1 & 21,3 & 41,8 \\
\hline & VV800 & 22,4 & 7,7 & 18 & 19,2 & 19 & 47,5 \\
\hline & VV4733 & 21,2 & 6,6 & 20 & 19,8 & 19,6 & 39 \\
\hline & VV3734 & 21 & 6,3 & 19,4 & 19,7 & 19,7 & 32,9 \\
\hline & VV2696 & 25,8 & 8,3 & 19,6 & 20,9 & 21,4 & 49,5 \\
\hline & VV3852 & 22,1 & 7,8 & 17,2 & 19,4 & 20,2 & 46,3 \\
\hline & VV811 & 24,6 & 6,5 & 20,1 & 19,4 & 20,1 & 47,1 \\
\hline & VV4649 & 24,5 & 7,2 & 20,5 & 19,6 & 20,5 & 47,1 \\
\hline & VV3279 & 21,2 & 6 & 18,3 & 18,8 & 18,5 & 40,1 \\
\hline & VV2568 & 21,4 & 5,9 & 18,1 & 18,4 & 18,7 & 43,1 \\
\hline & VV815 & 22,9 & 6,3 & 19,2 & 19 & 20,2 & 43,2 \\
\hline & VV3286 & 21,2 & 6,3 & 19,8 & 19,6 & 19,7 & 35,6 \\
\hline & VV2774 & 21,6 & 6,2 & 19,6 & 18,7 & 19,2 & 35,7 \\
\hline & VV812 & 19,3 & 5,8 & 18,2 & 18,3 & 18,4 & 23,3 \\
\hline & VV4793 & 19,8 & 5,9 & 21,3 & 19,2 & 20,8 & 16,9 \\
\hline & VV494 & 20,1 & 6,8 & 19,9 & 18,3 & 19,4 & 31 \\
\hline & VV835 & 20,7 & 6,9 & 20,4 & 19,7 & 20,2 & 20,8 \\
\hline & VV822 & 18,8 & 6,2 & 19,3 & 18,7 & 19,2 & 18,1 \\
\hline & VV802 & 19,8 & 7,4 & 20,6 & 19,1 & 20,5 & 21,5 \\
\hline & VV654 & 24,1 & 8 & 19,8 & 20,5 & 20,1 & 48,3 \\
\hline & VV549 & 26,1 & 8,1 & 20,7 & - & 22 & 52,5 \\
\hline & VV4206 & 19,1 & 6,6 & 20,7 & 19,1 & 20,7 & 14 \\
\hline & VV1816 & 18,4 & 6,1 & 18 & 18,4 & 18 & 10,9 \\
\hline & VV3842 & 18,4 & 7,1 & 19,1 & 18,4 & 19,1 & 8,5 \\
\hline & VV2916 & 18,6 & 6,1 & 20,6 & 18,6 & 20,6 & 11,7 \\
\hline & VV751 & 18,4 & 7 & 19,6 & 18,4 & 19,6 & 7 \\
\hline & VV804 & 18,5 & 6,1 & 20,3 & 18,5 & 20,3 & 8,5 \\
\hline & VV2578 & 18,5 & 6,4 & 21,3 & 18,5 & 21,3 & 11,2 \\
\hline & VV2578 & 18,8 & 6 & 20,3 & 18,8 & 20,3 & 12,4 \\
\hline & VV1606 & 19,2 & 5,9 & 19,6 & - & - & - \\
\hline & VV1606 & 19,5 & 5,5 & 18,5 & - & - & - \\
\hline & VV819 & 19,2 & 6,3 & 20,1 & - & - & - \\
\hline & VV819 & 18,6 & 6,6 & 19,5 & - & - & - \\
\hline & VV819 & 18,7 & 6,6 & 19,5 & - & - & - \\
\hline \multirow[t]{10}{*}{ M3 } & VV4510 & 19,4 & 7,3 & 15,8 & 19,6 & 18,2 & 42,3 \\
\hline & VV289 & 18,9 & 6,2 & 15,9 & 18,3 & 16,9 & 37,8 \\
\hline & VV3913 & 18,8 & 7,4 & 14,8 & 19,3 & 18,5 & 42,6 \\
\hline & VV3448 & 18,8 & 6,2 & 17,1 & 19,4 & 17,6 & 30,4 \\
\hline & VV4324 & - & - & - & 19,5 & 17 & 45,4 \\
\hline & VV3287 & 19,6 & 5,9 & 17,2 & 20,7 & 17,8 & 28,2 \\
\hline & VV2800 & 19,5 & 6,4 & 17,2 & 19,9 & 18,1 & 26,8 \\
\hline & VV3334 & 19,7 & 6 & 17,1 & 20,6 & 18,1 & 27,6 \\
\hline & VV618 & 18,7 & 6 & 16,7 & 17,9 & 17 & 29,5 \\
\hline & VV93a & 20,9 & 6 & 17,7 & 19,6 & 17,7 & 17,5 \\
\hline
\end{tabular}




\begin{tabular}{|c|c|c|c|c|c|c|c|}
\hline & & 1 & 2 & 3 & 4 & 5 & 6 \\
\hline \multirow[t]{10}{*}{ M3 } & VV836 & 19,6 & 6,4 & 17,6 & 20,3 & 18,3 & 0,27 \\
\hline & VV4504 & 19,2 & 6,1 & 17,2 & 19,2 & 17,2 & 8,8 \\
\hline & VV2755 & 18,6 & 6,8 & 17,2 & 18,6 & 17,2 & 11,2 \\
\hline & VV2914 & 17,4 & 5,8 & 15,8 & 17,4 & 15,8 & 9,1 \\
\hline & VV1692 & 20,4 & 8 & 17,8 & 20,4 & 17,8 & 8,3 \\
\hline & VV764 & 21,8 & 7,9 & 18,2 & - & - & 8,8 \\
\hline & VV2578 & 19,2 & 6,4 & 18,3 & 19,2 & 18,3 & 13,5 \\
\hline & VV1606 & 21 & 5,8 & 16,8 & - & - & - \\
\hline & VV819 & 18 & 6,6 & 17,6 & - & - & - \\
\hline & VV819 & 16,8 & 6,4 & 17,7 & - & - & - \\
\hline \multirow[t]{12}{*}{ p2 } & VV4713 & 26,6 & 8,6 & 12,8 & 26,8 & 12 & 19,3 \\
\hline & VV3556 & 24,7 & 10,3 & 11,3 & 24,7 & 12,3 & 10,4 \\
\hline & VV4702 & 25,3 & 11,3 & 20 & - & 11,4 & 29,1 \\
\hline & VV838 & 25,2 & 10,8 & 12,3 & 24,6 & 12,6 & 13,2 \\
\hline & VV3307 & 24,7 & 11,3 & 12,7 & 13,3 & 11,6 & 26,1 \\
\hline & VV5318 & - & 10,2 & 13,4 & - & 12,3 & 20,4 \\
\hline & VV3330 & 27,8 & 12,4 & 12,2 & 27,4 & 12,7 & 31,9 \\
\hline & VV687 & 26,3 & 11,2 & 13,1 & 24,9 & 12,9 & 16,9 \\
\hline & VV3372 & 27 & 11,8 & 12,5 & 25,9 & 11,8 & 30,7 \\
\hline & VV439 & 24,6 & 10,8 & 11,7 & 23,5 & 11,7 & 26,6 \\
\hline & VV817 & 23,8 & 10,6 & 12,7 & - & - & 12,9 \\
\hline & VV1492 & 24,9 & 10,8 & 12,7 & - & - & 0,14 \\
\hline \multirow[t]{28}{*}{ p3-4 } & VV3797 & 22,5 & 11,7 & 14 & 20,4 & 13,3 & 34,9 \\
\hline & VV3672 & 21,9 & 9,6 & 12,9 & 21,1 & 12,6 & 35,4 \\
\hline & VV4207 & 22,9 & 9,5 & 13,2 & 22,2 & 11,6 & 25,5 \\
\hline & VV4203 & 23 & 10,4 & 12,8 & 21,1 & 12,1 & 45,2 \\
\hline & VV2913 & 22,4 & 10,4 & 13,7 & 22,3 & 12,6 & 0,15 \\
\hline & VV2879 & 21,9 & 9,8 & 13,3 & 21,1 & 13,2 & 28,5 \\
\hline & VV2029 & 22,9 & 11,1 & 13,8 & 22,3 & 13,9 & 19,6 \\
\hline & VV813 & 21,1 & 8,2 & 13,3 & 21,1 & 13,3 & 13,5 \\
\hline & VV5119 & 22 & 10,6 & 13,2 & 21,1 & 13,3 & 13,5 \\
\hline & VV1694 & 22 & 11,2 & 13,7 & 20,4 & 13,4 & 41,6 \\
\hline & VV3001 & 22,3 & 9,6 & 13 & 21,8 & 13,2 & 28,4 \\
\hline & VV1811 & 22,8 & 9,9 & 12,8 & 20,7 & 13 & 28,6 \\
\hline & VV2915 & 23,1 & 11,2 & 13,9 & 22,1 & 12,8 & 26,9 \\
\hline & VV3033 & 25 & 11,3 & 11,1 & 22 & 13,1 & 54,5 \\
\hline & VV4800 & 25,1 & 11,8 & 13,1 & 22,4 & 12,6 & 45,2 \\
\hline & VV1761 & 21,9 & 10,9 & 12,3 & 20,3 & 14,1 & 41,3 \\
\hline & VV3812 & 22,8 & 12,1 & 13,1 & 22,9 & 14,7 & 26,1 \\
\hline & VV5225 & 22,5 & 11,4 & 12 & 21,4 & 12,4 & 35,8 \\
\hline & VV823 & 23 & 11,2 & 12,3 & - & 12,2 & 37,4 \\
\hline & VV2117 & 21,6 & 10,8 & 12,5 & 21,2 & 12,9 & 27,7 \\
\hline & VV1297 & 19,4 & 6,9 & 10,8 & 18,8 & 11,9 & 0,17 \\
\hline & VV817 & 21,1 & 11,3 & 14 & - & - & - \\
\hline & VV817 & 21,3 & 10,4 & 13,7 & - & - & - \\
\hline & VV817 & 20,4 & 10,2 & 13 & - & - & - \\
\hline & VV817 & 19,8 & 10 & 12 & - & - & - \\
\hline & VV1492 & 22,4 & 10,3 & 13,9 & - & - & - \\
\hline & VV1492 & 20,9 & 9,2 & 13,7 & - & - & - \\
\hline & VV169 & 21,3 & 8,7 & 11,9 & 20,4 & 13,6 & 21,7 \\
\hline \multirow[t]{5}{*}{ m1-2 } & VV4747 & 24,5 & 10,4 & 10,2 & 19,6 & 10,3 & 48,6 \\
\hline & VV4824 & 23,6 & 9,6 & 10,1 & 19,5 & 10,2 & 45,4 \\
\hline & VV3072 & 24 & 10 & 9,8 & 19,2 & 10,7 & 51,6 \\
\hline & VV5341 & 25,5 & 10,6 & 10,1 & 19,7 & 11,1 & 50,8 \\
\hline & VV1344 & 20,7 & 8 & 11,4 & 17,5 & 11,8 & 36,8 \\
\hline
\end{tabular}




\begin{tabular}{|c|c|c|c|c|c|c|c|}
\hline & & 1 & 2 & 3 & 4 & 5 & 6 \\
\hline \multirow[t]{28}{*}{ m1-2 } & VV2868 & 20,1 & 7,5 & 11 & 19,3 & 11,4 & 24,1 \\
\hline & VV1590 & 20,5 & 7,8 & 11,3 & 19,8 & 11,2 & 23,7 \\
\hline & VV5206 & 22,8 & 10,1 & 10,2 & 20,7 & 10,7 & 42,9 \\
\hline & VV839 & 20,9 & 8,1 & 10,2 & 19,8 & 10,3 & 22,8 \\
\hline & VV3615 & 19,4 & 7,1 & 10,7 & 18,9 & 11,2 & 16,1 \\
\hline & VV3649 & 19,6 & 6,9 & 10 & 19 & 11,5 & 18,9 \\
\hline & VV1826 & 18,2 & 4,4 & 10,1 & 18,2 & 10,1 & 6,8 \\
\hline & VV4703 & 18,3 & 5,9 & 10,7 & 18 & 10,6 & 21,7 \\
\hline & VV3323 & 25,8 & 10,4 & 9,9 & 19,4 & 10,6 & 52,9 \\
\hline & VV3844 & 20 & 7,4 & 10,6 & - & - & 39,9 \\
\hline & VV4208 & 20,8 & 8,1 & 10,1 & 19 & 10,2 & 22,6 \\
\hline & VV2627 & 22,6 & 9,6 & 9,6 & 19,6 & 10,4 & 45,3 \\
\hline & VV3243 & - & 7,3 & 9,4 & - & 9,4 & 19,2 \\
\hline & VV4735 & 21,6 & 9,4 & 9,2 & 18,1 & 9,5 & 44,5 \\
\hline & VV3777 & 19,1 & 7,2 & 10,2 & 17,6 & 10 & 2,6 \\
\hline & VV443 & 25,1 & 11,1 & 9,5 & 19,2 & 11,4 & 53,3 \\
\hline & VV5179 & 25,9 & 10,2 & 9,6 & 18,4 & 11,4 & 55,5 \\
\hline & VV2117 & 20,7 & 8,2 & 12,7 & 19,5 & 11,2 & 20,1 \\
\hline & VV5179 & 25,7 & 10,1 & 10,3 & - & 11,5 & 55,8 \\
\hline & VV2173 & 18,3 & 4,7 & 11,2 & 18,3 & 11,2 & 8 \\
\hline & VV817 & 18,4 & 6,5 & 10,8 & - & - & - \\
\hline & VV817 & 18,2 & 6,5 & 11,1 & - & - & - \\
\hline & VV817 & 18,1 & 7,1 & 10,1 & - & - & - \\
\hline & VV817 & 18,8 & 7 & 10,3 & - & - & - \\
\hline & VV1492 & 19,2 & 6,4 & 12,4 & - & - & - \\
\hline & VV1492 & 18,6 & 6,9 & 11,1 & - & - & - \\
\hline & VV169 & 18,4 & 6,1 & 11,4 & 18,3 & - & - \\
\hline & VV169 & 19,6 & 6,6 & 11 & 19,7 & 12,4 & 15,5 \\
\hline \multirow[t]{8}{*}{ m3 } & VV808 & 21,2 & 9,3 & 8,3 & 24,1 & 9,4 & 45 \\
\hline & VV2751 & - & 8,7 & 8,2 & - & - & 23,8 \\
\hline & VV1486 & 25 & 5,2 & 10,4 & 25 & 10,4 & 7,6 \\
\hline & VV4851 & 22,9 & 7,9 & 10,2 & 23,1 & 9,9 & 22,8 \\
\hline & VV4792 & 20,8 & 8,4 & 8,6 & 22,7 & 9,4 & 46,4 \\
\hline & VV3146 & 23,4 & 7,5 & 9,9 & 23,9 & 9,6 & 36,8 \\
\hline & VV4222 & 23 & 7,5 & 9,5 & 23,4 & 8,9 & 30,3 \\
\hline & VV1492 & 22,8 & 7,2 & 10,3 & - & - & 21,6 \\
\hline
\end{tabular}


Table 3

\begin{tabular}{|c|c|c|c|c|c|c|c|c|c|c|c|c|c|c|c|}
\hline & & 1 & 2 & 3 & 4 & 5 & 6 & 7 & 8 & 9 & 10 & 11 & 12 & 13 & 14 \\
\hline \multirow[t]{29}{*}{ 1FIII } & VV1094 & 52,1 & 47,6 & 22,5 & 32,6 & 25,7 & 27,6 & 26,4 & 17,9 & - & - & - & - & - & - \\
\hline & VV3172 & 57,9 & 51,7 & 23,3 & 34,2 & 26,9 & 29,1 & 29,1 & 17,2 & - & - & - & - & - & - \\
\hline & VV2651 & 58,2 & 53,4 & 24 & 34,8 & 26,7 & 27,6 & 27,5 & 17,4 & - & - & - & - & - & - \\
\hline & VV4707 & 55 & 50,9 & 22,9 & 31,4 & 27 & 27,3 & 26,7 & 16,6 & - & - & - & - & - & - \\
\hline & VV824 & 53,3 & 47,4 & 23 & 31,4 & - & 27,4 & 27,8 & 16,1 & - & - & - & - & - & - \\
\hline & VV5172 & 52,8 & 48,8 & 20,7 & 28,1 & 24,3 & 26 & 24,5 & 14,5 & - & - & - & - & - & - \\
\hline & NM3109 & 53,5 & 49,2 & 22,8 & 31,7 & 26,6 & 26,8 & 26,9 & 26,5 & - & - & - & - & - & - \\
\hline & NM3939 & 56,3 & 51,2 & 23,2 & 31,9 & 27,5 & 27,3 & 26,7 & 16,3 & - & - & - & - & - & - \\
\hline & NM3111 & 55,8 & 51,4 & 22,4 & 32,2 & 27 & 27,9 & 28,2 & 16,2 & - & - & - & - & - & - \\
\hline & $\mathrm{S} / \mathrm{S}$ & 56,7 & 51,9 & 23,1 & 31,7 & 27,8 & 28,7 & 28 & 16,3 & - & - & - & - & - & - \\
\hline & ZV312 & 55,8 & 50,6 & 24 & 31,9 & 26,5 & 27,3 & 27,8 & 15,3 & - & - & - & - & - & - \\
\hline & NM3115 & 54,5 & 50,3 & 23,8 & 30,4 & 23,1 & 27,2 & 27,1 & 15,6 & - & - & - & - & - & - \\
\hline & ZV313 & 51,9 & 46,4 & 21,1 & 31,3 & - & 25,8 & 26,4 & 15,5 & - & - & - & - & - & - \\
\hline & VV2581 & 58,1 & 52,8 & 21,7 & 32,2 & 25,4 & 25,7 & 27,1 & 15,9 & - & - & - & - & - & - \\
\hline & VV1821 & 57,3 & 53,7 & 22,5 & 32,2 & 23,5 & 26,4 & 27,7 & 15,6 & - & - & - & - & - & - \\
\hline & VV292 & 55,8 & 51,5 & 21,1 & 31,8 & 24,6 & 26,1 & 27,3 & & - & - & - & - & - & - \\
\hline & VV3316 & 64,6 & 60 & 21,6 & - & 25,4 & 27,7 & 28,1 & 14,8 & - & - & - & - & - & - \\
\hline & NM3930 & 61,4 & 57,4 & 22,7 & 34,6 & 26,6 & 28,4 & 28,4 & 17,8 & - & - & - & - & - & - \\
\hline & NM3930 & 61,4 & 57,4 & 22,7 & 34,6 & 26,6 & 28,4 & 28,4 & 17,8 & - & - & - & - & - & - \\
\hline & NM3110 & 54,6 & 51,8 & 21,5 & 31,6 & 23,6 & 27,1 & 28 & 14,8 & - & - & - & - & - & - \\
\hline & VV434 & - & - & 23,9 & - & - & 28,6 & 27,6 & 15,1 & - & - & - & - & - & - \\
\hline & VV1597 & - & - & 20,6 & - & - & - & - & - & - & - & - & - & - & - \\
\hline & VV2001 & - & - & - & - & - & 24,2 & 26,8 & - & - & - & - & - & - & - \\
\hline & VV2009 & & 46,8 & 18,1 & - & - & 23,5 & 24,7 & 13,8 & - & - & - & - & - & - \\
\hline & $\mathrm{S} / \mathrm{S}$ & - & - & - & 29,8 & 22,6 & - & - & - & - & - & - & - & - & - \\
\hline & $\mathrm{S} / \mathrm{S}$ & - & - & - & 32,1 & 0,24 & - & - & - & - & - & - & - & - & - \\
\hline & $\mathrm{S} / \mathrm{S}$ & - & 50,5 & 21,7 & - & - & 26,8 & 27,8 & 15,2 & - & - & - & - & - & - \\
\hline & $\mathrm{S} / \mathrm{S}$ & - & - & 20,8 & - & 21,8 & - & - & - & - & - & - & - & - & - \\
\hline & NM20006 & - & - & - & 30,5 & 23,3 & - & - & - & - & - & - & - & - & - \\
\hline \multirow[t]{16}{*}{ AST. } & VV3175 & 44,8 & 47,9 & 20,3 & 47,7 & 37,4 & 27,8 & 39,2 & - & - & - & - & - & - & - \\
\hline & VV3723 & 46 & 44,8 & 21,4 & 43,4 & 34,1 & 25 & 35,2 & - & - & - & - & - & - & - \\
\hline & VV3267 & 48,4 & 43,7 & 20,3 & 44,7 & 37,4 & 24,7 & 36,2 & - & - & - & - & - & - & - \\
\hline & VV285 & 48,1 & 46,9 & 20,6 & 45,7 & 33,9 & 25,9 & 37,9 & - & - & - & - & - & - & - \\
\hline & VV5229 & 45,9 & 46,2 & 21,2 & 43,3 & 33,7 & 29,1 & 37,1 & - & - & - & - & - & - & - \\
\hline & VV696 & 53,1 & 54,2 & 29 & 53 & 41,2 & 30,1 & 44,7 & - & - & - & - & - & - & - \\
\hline & VV3731 & 47,1 & 48,7 & 21,6 & 44,8 & 36,1 & 27,1 & 38,7 & - & - & - & - & - & - & - \\
\hline & VV3304 & 42,7 & 40,9 & 18,8 & 39,3 & 28,9 & 22,1 & 31,6 & - & - & - & - & - & - & - \\
\hline & VV1893 & 40,1 & 38,9 & 16,9 & 36,8 & 27,9 & 22,3 & 30,8 & - & - & - & - & - & - & - \\
\hline & VV4572 & 45,6 & 43,6 & 20,1 & - & 33,6 & 25,2 & - & - & - & - & - & - & - & - \\
\hline & VV3113 & 47,4 & - & 20,4 & - & 34,9 & 26,5 & - & - & - & - & - & - & - & - \\
\hline & VV816 & 46,3 & - & 21,2 & - & - & - & - & - & - & - & - & - & - & - \\
\hline & VV487 & - & 46,2 & - & - & - & - & - & - & - & - & - & - & - & - \\
\hline & VV5110 & 44,8 & 43,2 & 19,1 & 0,43 & - & - & - & - & - & - & - & - & - & - \\
\hline & VV1428 & 47,1 & - & 21,7 & 45,5 & - & - & - & - & - & - & - & - & - & - \\
\hline & VV3099 & 44,7 & - & 20 & - & - & - & - & - & - & - & - & - & - & - \\
\hline \multirow[t]{10}{*}{ McIII } & VV2563 & 208,1 & 200,6 & 20,8 & 20,4 & 34,1 & - & 29,1 & 10,5 & 3,5 & 29,9 & - & 22,5 & 18,3 & 21,6 \\
\hline & VV699 & 219,6 & 211,6 & 22,1 & 20,9 & - & 22,6 & - & 7,6 & - & 31,6 & - & 23,4 & 19,9 & 21,5 \\
\hline & VV1608 & 207 & 201,8 & 21,3 & 20,4 & 34,5 & - & 30,1 & 8,3 & 3,6 & 31,9 & - & 24,7 & 20,4 & 22,4 \\
\hline & VV4215 & 214,4 & 209,8 & 21 & 19,8 & - & - & - & 6,7 & - & 31 & - & 24,3 & 19,5 & 21,9 \\
\hline & NM3839 & 200,4 & 194,8 & 21,8 & 19,4 & 31,9 & 19,3 & 27,1 & 6,3 & 3,2 & 30,4 & - & 25,4 & 20 & 21,8 \\
\hline & $\mathrm{S} / \mathrm{S}$ & 199,2 & - & 20,2 & 18,2 & - & 21 & - & 7,9 & - & 29,1 & - & 23,9 & 19,6 & \\
\hline & $\mathrm{S} / \mathrm{S}$ & 215,8 & 209,2 & 21,9 & 20 & 33,2 & 21,3 & 29 & 8,8 & 3,7 & 30,3 & - & 25,6 & 21,1 & 22,3 \\
\hline & VV4685 & - & - & - & - & 32,2 & 21,4 & 27,9 & 8,2 & 2,8 & - & - & - & - & - \\
\hline & NM3889 & - & - & - & - & 32,2 & 21,3 & 28,1 & 8,6 & 3,8 & - & - & - & - & - \\
\hline & ZV307 & - & - & - & - & 29,9 & 20 & 27,6 & 8,3 & - & - & - & - & - & - \\
\hline
\end{tabular}




\begin{tabular}{llcccccccccccccc}
\hline & & $\mathbf{1}$ & $\mathbf{2}$ & $\mathbf{3}$ & $\mathbf{4}$ & $\mathbf{5}$ & $\mathbf{6}$ & $\mathbf{7}$ & $\mathbf{8}$ & $\mathbf{9}$ & $\mathbf{1 0}$ & $\mathbf{1 1}$ & $\mathbf{1 2}$ & $\mathbf{1 3}$ & $\mathbf{1 4}$ \\
\hline \multirow{2}{*}{ McIII } & ZV305 & - & - & - & - & 34,5 & 23 & 29,5 & 8,5 & 3,9 & - & - & - & - & - \\
NM3921 & - & - & - & - & 30,9 & 21,9 & 27,5 & 7 & - & - & - & - & - & - \\
NIS & - & - & - & - & 34,2 & - & 30,1 & 8,8 & 8,3 & - & - & - & - & - \\
MIII IV3171 & 235 & 228,8 & 21,2 & 27,2 & 35,8 & 27,8 & 33,2 & 7,7 & 6,3 & 31,8 & 30,7 & 28 & 20,5 & 23,8 \\
& VVI501 & 229,2 & 222 & & 24,1 & 34,4 & 27,6 & 33,1 & 7,6 & 5,2 & 31,5 & 30,3 & 26,7 & 19,7 & 22,7 \\
VV450, & VV374 & 234,4 & 227,1 & 23,7 & 25,6 & 34,5 & 27 & 31,8 & 8,5 & 5,5 & & 29,1 & 26,2 & 20,6 & 22,9 \\
S/S & - & - & 20,4 & 22,9 & - & - & - & - & - & 30,5 & 29,7 & 25,5 & 18,9 & 21,7 \\
NM3313 & 232,4 & 227,4 & 21,8 & 23,8 & 32,2 & - & 30,6 & 7,3 & - & 30,3 & 27,8 & 22,7 & 18 & 19,1 \\
NM3840 & 235 & 229,1 & 22,7 & 24,8 & 36,4 & 35,9 & 32,9 & 8,3 & 4,3 & 33,5 & 32,6 & 28,8 & 21,9 & 25,1 \\
VV702 & - & - & 21.3 & 24.2 & - & - & - & - & - & - & - & - & - & - \\
VV3011 & - & - & 21,1 & 25 & - & - & - & - & - & - & - & - & - & - \\
S/S & - & - & - & - & 35,9 & 26,8 & 32,8 & 8,1 & 5,6 & - & - & - & - & - \\
NM3984 & - & - & 22,4 & 23,8 & 32 & 26 & 30,8 & 6,3 & - & - & - & - & - & - \\
NM18117 & - & - & - & - & 32,9 & 23,6 & 29,8 & 7,05 & - & - & - & - & - & - \\
S/S & - & - & 21,5 & 23,8 & 32,6 & - & - & - & - & - & - & - & - & - \\
NM3980 & - & - & 21,9 & 23,5 & 37,4 & - & 33 & - & 4,9 & - & - & - & - & - \\
VV1479 & - & - & 20,8 & 24,1 & - & - & - & - & - & - & - & - & - & - \\
VV3273 & - & - & 22,8 & 24,1 & - & - & - & - & - & - & - & - & - & - \\
VV4756 & - & - & 21.8 & 24.6 & 32.0 & - & - & 8.6 & - & - & - & - & - & - \\
\hline
\end{tabular}


Table 4

\begin{tabular}{lccccccccc}
\hline & \multicolumn{3}{c}{ MtIII (1/3) } & \multicolumn{3}{c}{ McIII (1/3) } & \multicolumn{3}{c}{ MtIII (1/11) } \\
& N & Sd & X & N & Sd & X & N & Sd & X \\
\hline H. concudense Cerro de la Garita & $(8)$ & 0,7 & 11,8 & $(8)$ & 1,06 & 12,7 & $(8)$ & 0,42 & 14,8 \\
H. matthewi Milagros & $(2)$ & 0,51 & 9,7 & $(2)$ & 0,64 & 11,8 & $(2)$ & 0,15 & 13,4 \\
H. gmatthewi El Arquillo & $(1)$ & - & 10,6 & - & - & - & & & \\
H. matthewi Las Casiones & $(1)$ & - & 11 & $(1)$ & - & 14,2 & $(1)$ & - & 13,3 \\
H. periafricanum Las Casiones & $(4)$ & 0,3 & 8,9 & $(2)$ & 0,59 & 9,8 & $(4)$ & 0,4 & 11,3 \\
Hipparion Venta del Moro & $(6)$ & 0,37 & 9,5 & $(9)$ & 0,4 & 10,3 & $(7)$ & 0,6 & 12,8 \\
H. matthewi Pavlodar & $(19)$ & 0,59 & 9,6 & $(19)$ & 0,51 & 11 & $(19)$ & 0,55 & 12,3 \\
C. matthewi Sahabi & $(2)$ & 0,91 & 9,1 & $(1)$ & & 10,7 & $(2)$ & 2,04 & 13,1 \\
C. matthewi Samos & $(3)$ & 0,51 & 8,7 & $(7)$ & 1,32 & 10,5 & (3) & 0,25 & 11,1 \\
\hline
\end{tabular}




\begin{tabular}{ccc}
\hline \multicolumn{3}{c}{ McIII (1/11) } \\
$\mathbf{N}$ & Sd & $\mathbf{X}$ \\
\hline$(8)$ & 0,84 & 15,9 \\
$(2)$ & 1,22 & 15,6 \\
- & - & - \\
$(1)$ & - & 17,1 \\
$(2)$ & 0,68 & 13,1 \\
$(9)$ & 0,51 & 14,1 \\
$(19)$ & 0,51 & 14,1 \\
$(1)$ & - & 16 \\
$(7)$ & 0,8 & 12,8 \\
\hline
\end{tabular}




\begin{tabular}{|c|c|c|c|c|c|c|c|c|c|}
\hline & & & & & & & \multicolumn{3}{|c|}{ VM H. matthewi } \\
\hline & \multicolumn{3}{|c|}{ McIII } & \multicolumn{3}{|c|}{ MtIII } & \multicolumn{3}{|c|}{ Ast } \\
\hline & 1 & 3 & 7 & 1 & 3 & 7 & 1 & 2 & 4 \\
\hline VM H. matthewi ssp & & & & & & $5,25^{\star}$ & $5,80^{*}$ & 4,83 & \\
\hline KS H. matthewi & & & & & & & 1,14 & 0,51 & $-1,62$ \\
\hline KS H. periafricanum & $63,54^{*}$ & $6,85^{\star}$ & $9,84^{*}$ & $65,66^{\star}$ & $6,96^{*}$ & $11,43^{*}$ & $16,11^{*}$ & $16,32^{*}$ & $14,23^{\star}$ \\
\hline ML H. matthewi & & & & $24,54^{\star}$ & 1,34 & $2,65^{\star}$ & $3,99 *$ & $3,02^{*}$ & 2,36 \\
\hline PAV H. elegans & $9,16^{*}$ & $-0,45$ & 0,23 & 2,74 & $-0,33$ & 0,55 & $1,93^{*}$ & 1,56 & $-0,92$ \\
\hline SA H. matthewi & $-0,069$ & $-0,48$ & $-0,006$ & & & & & & \\
\hline SH H. matthewi & & & & $-12,01$ & $-1,74$ & $-3,25^{\star}$ & & & \\
\hline CG H.concudense & $-2,18$ & $-5,13^{*}$ & $-2,68^{\star}$ & $-8,81$ & $-6,59 *$ & $-3,28^{*}$ & $-6,62^{*}$ & $-7,34^{\star}$ & $-9,33^{\star}$ \\
\hline $\mathrm{HO}$ H. primigenium & $-4,4$ & $-9,98^{*}$ & $-6,05$ & $-10,44^{*}$ & $-8,78^{*}$ & $-7,91^{*}$ & $-11,59 *$ & $-12,64^{*}$ & $-17,01^{*}$ \\
\hline
\end{tabular}




\begin{tabular}{|c|c|c|c|c|c|}
\hline \multicolumn{3}{|c|}{ 1PhIII ant } & \multicolumn{3}{|c|}{ 1PhIll post } \\
\hline 1 & 3 & 5 & 1 & 3 & 5 \\
\hline 4,56 & 0,29 & 0,47 & 0,82 & $-0,23$ & $-0,31$ \\
\hline $16,46^{*}$ & $7,67^{*}$ & $7,67^{*}$ & $15,47^{\star}$ & $7,99^{\star}$ & $8,09 *$ \\
\hline 7,85 & $2,52^{*}$ & 2,22 & $8,22^{*}$ & $3,79^{\star}$ & 1,67 \\
\hline$-3,11$ & 0,73 & $-0,69$ & 1,10 & 0,53 & $-1,18$ \\
\hline$-1,53$ & $-3,81^{*}$ & $-3,04$ & $-3,07^{*}$ & $-3,97^{*}$ & $-3,54^{*}$ \\
\hline$-2,21$ & $-7,71^{\star}$ & $-4,49$ & $-8,87^{*}$ & $-7,76^{*}$ & $-7,21^{*}$ \\
\hline
\end{tabular}


Table 6

\begin{tabular}{|c|c|c|c|c|c|}
\hline $\begin{array}{l}\text { Principal } \\
\text { component } \\
\text { of limb } \\
\text { bones } \\
\end{array}$ & $\begin{array}{c}\text { Number of } \\
\text { character }\end{array}$ & Eigen value & $\begin{array}{l}\text { Principal } \\
\text { component } \\
\text { of limb } \\
\text { bones }\end{array}$ & $\begin{array}{c}\text { Number of } \\
\text { character }\end{array}$ & Eigen value \\
\hline McIll & & & Astragalus & & \\
\hline \multirow[t]{3}{*}{ First component } & 5 & 0,972 & First component & 4 & 0,985 \\
\hline & 14 & 0,965 & & 2 & 0,983 \\
\hline & 11 & 0,951 & & 1 & 0,981 \\
\hline \multirow[t]{2}{*}{ Second component } & 2 & 0,547 & Second component & 3 & 0,326 \\
\hline & 1 & 0,539 & & & \\
\hline MtIII & & & First phalanx & & \\
\hline \multirow[t]{3}{*}{ First component } & 7 & 0,982 & First component & 4 & 0,963 \\
\hline & 13 & 0,98 & & 3 & 0,955 \\
\hline & 10 & 0,977 & & 6 & 0,948 \\
\hline \multirow[t]{2}{*}{ Second component } & 2 & 0,472 & Second component & 2 & 0,512 \\
\hline & 1 & 0,443 & & 1 & 0,457 \\
\hline
\end{tabular}


Table 7

\begin{tabular}{lcccccc}
\hline & Original & $\mathrm{N}$ & 1 & 2 & 3 & 4 \\
\hline McIII & 1 & 6 & $100 \%(6)$ & 0 & 0 & 0 \\
& 2 & 12 & 0 & $100 \%(12)$ & 0 & 0 \\
& 3 & 1 & 0 & 0 & $100 \%(1)$ & 0 \\
& 4 & 2 & 0 & 0 & 0 & $100 \%(2)$ \\
\hline MtIII & 1 & 19 & $94,7 \%(18)$ & $0 \%$ & $5,3 \%(1)$ & $0 \%$ \\
& 2 & 17 & $0 \%$ & $100 \%(17)$ & $0 \%$ & $0 \%$ \\
& 3 & 2 & $0 \%$ & $0 \%$ & $100 \%(2)$ & $0 \%$ \\
\hline Astragalus & 4 & 5 & $0 \%$ & $0 \%$ & $0 \%$ & $100 \%(5)$ \\
& 1 & 77 & $87 \%(67)$ & 0 & $11,7 \%(9)$ & $1,3 \%(1)$ \\
& 2 & 20 & $0 \%$ & $100 \%(20)$ & $0 \%$ & $0 \%$ \\
& 3 & 8 & $0 \%$ & $0 \%$ & $100 \%(8)$ & $0 \%$ \\
& 4 & 18 & $5,6 \%(1)$ & $0 \%$ & $0 \%$ & $94,4 \%(17)$ \\
\hline First phalanx & 1 & 48 & $87,5 \%(42)$ & $0,00 \%$ & $4,2 \%(2)$ & $8,3 \%(4)$ \\
& 2 & 35 & $0,00 \%$ & $94,3 \%(33)$ & $100 \%$ & $5,7 \%(2)$ \\
\end{tabular}

